\title{
PRELIMINARY CHECK-LIST OF PLANKTON ORGANISMS FOUND IN TANABE BAY AND ITS ENVIRONS
}

$\operatorname{AUTHOR(S):~}$

Yamazi, Isamu

\section{CITATION:}

Yamazi, Isamu. PRELIMINARY CHECK-LIST OF PLANKTON ORGANISMS FOUND IN TANABE BAY AND ITS ENVIRONS. PUBLICATIONS OF THE SETO MARINE BIOLOGICAL LABORATORY 1958, 7(1): 111-163

\section{ISSUE DATE:}

1958-12-20

URL:

http://hdl.handle.net/2433/174597

RIGHT: 


\title{
PRELIMINARY CHECK-LIST OF PLANKTON ORGANISMS FOUND IN TANABE BAY AND ITS ENVIRONS ${ }^{1)}$
}

\author{
ISAMU YAMAZI
}

Seto Marine Biological Laboratory, Sirahama

This list of common plankton organisms found in Tanabe Bay and its environs is prepared mainly for the use of planktologists and for researchers or students learning the practical exercises in marine biology at our Laboratory, in order to indicate the general distribution of plankton organisms around the coast and to form a basis for a more complete list of the species occurring in our waters. The environmental conditions are briefly described for each common or characteristic species, with some short notes on their ecology.

In this list is excluded either of the transitory plankton such as those benthic forms that have a planktonic larval stage or the epibionts on planktonic or floating objects or organisms. The holoplankton organisms comprising both phyto- and zooplankton listed herein are summerized below.

\begin{tabular}{l|c|c|c|c|c}
\hline & Class & $\begin{array}{c}\text { Subclass } \\
\text { or } \\
\text { Order }\end{array}$ & Family & Genus & Species \\
\hline Cyanophyceae (Blue-green Algae) & 1 & 1 & - & 1 & 1 \\
Bacillariaceae (Diatoms) & 1 & 2 & 17 & 47 & 175 \\
Mastigophora & 1 & 2 & 4 & 21 & 82 \\
Sarcodina & 1 & 2 & - & 37 & 41 \\
Ciliophora & 1 & 1 & 12 & 26 & 54 \\
Hydrozoa & 1 & 3 & - & 47 & 54 \\
Scyphozoa & 1 & 3 & - & 10 & 10 \\
Anthożoa & 1 & 1 & - & 1 & 1 \\
Ctenophora & 1 & 4 & - & 9 & 9 \\
Rotifera & 1 & 1 & - & 2 & 2 \\
Chaetopoda & 1 & - & - & 6 & 18 \\
Chaetognatha & 1 & - & - & 5 & 16 \\
Gastropoda & 1 & 3 & - & 16 & 34 \\
Crustacea & 1 & 8 & 36 & 81 & 244 \\
Tunicata & 1 & 3 & - & 15 & 37 \\
\hline & 15 & 34 & 69 & 324 & 778 \\
\hline
\end{tabular}

1) Contributions from the Seto Marine Biological Laboratory, No. 319.

Publ. Seto Mar. Biol. Lab., VII (1), 1958. (Article 5) 
The genera are listed alphabetically under the order or family and species alphabetically under the genus. Main synonyms are shown in brackets, when necessary.

The present list includes also the species that have been recorded by many authors and some unpublished species sketched or recorded by the late Mr. Jiro IKaRI, for. merly a member of our Laboratory staff.

The macroplankton samples have been collected with larval net which is one meter in diameter at the mouth and 2.6 meters long with silk bolting gauze at the upper and middle part ( 29 meshes/inch) and at the bottom ( 39 meshes/inch). The net was hauled horizontally for three minutes at each station from July, 1955 to January, 1957 in Tanabe Bay (HARAdA, 1957).

The microplankton samples have been at times collected with KITAHARA's standard net, modified from HENSEN's net, with ca. $20 \mathrm{~cm}$ mouth diameter and $100 \mathrm{~cm}$ long, stretched with silk bolting gauze $(\mathrm{XX}-14)$, hauling vertically from the bottom to the surface during the years from 1954 to 1958 (YAMAZI, 1955; YAMAZI, 1958).

The author wishes to express his sincere thanks to Mr. E. Harada for affording the materials of macroplankton and to Dr. Huzio Utinomi and Dr. Takasi TokiokA for their kindness in giving valuable suggestions and in revising the scientific names in the preparation of the manuscript. The author is also indebted to the Japanese National Commission for UNESCO and the Ministry of Education for Grants-in-Aid to this study. 


\section{LIST OF THE SPECIES}

\section{Class CYANOPHYCEAE (Blue-green Algae)}

\section{Order HORMOGONEAE}

\section{Trichodesmium erythraeum EHRENBERG}

Trichodesmium Tiebauti GoM.

Occurs in swarms, in open sea water outside the bay, chiefly in summer and autumn. Oceanic, tropical form. (YAMAZI, 1959, p. 38, 53, 160)

\section{Class BACILLARIACEAE (Diatoms) \\ Order CENTRALES \\ Suborder DISCINEAE}

\section{Family 1. Melosiraceae}

Melosira numuloides (Dillw.) Agardh

Rare, in littoral and brackish water area. Tichopelagic, eurythermal form.

Melosira sulcata (EHRENBERG) Kützing

Not very common, inside the bay, in winter and spring. Tichopelagic, north-temperate form.

\section{Family 2. Coscinodiscaceae}

\section{Actinoptychus undulatus (BAIL.) RALFS}

Very rare in all seasons, occurs accidentally in plankton. Neritic and littoral, north and south temperate species. (YAMAZI, 1959, p. 22, 136)

Arachnoidiscus ornatus (BRÉB.) GREv.

Asteromphalus heptactis (BRÉB.) RALFS

Very rare, occasionally in winter and spring. Oceanic, temperate or subtropical species. (YamAzi, 1959, p. 214)

Coscinodiscus asteriomphalus EHRENBERG

Common in spring and summer, outside and inside the bay. South-temperate species.

Coscinodiscus centralis EHRENBERG

Rare, inside and outside the bay, in the cold season. Oceanic and neritic, temperate or north temperate species. (YAMAZI, 1959, p. 134)

\section{Coscinodiscus concinnus W. SMtTH}

Rare, widely distributed, chiefly in winter and spring. Neritic, north temperate, euryhaline species.

\section{Coscinodiscus excentricus EHRENBERG}

Rare in the bay, in autumn and winter. Chiefly oceanic but frequently neritic. 


\section{Coscinodiscus gigas EHRENBERG}

Commonest, especially in the cold season, inside and outside the bay, widely distributed, in almost all seasons. (YAMAZI, 1959, p. 21, 33, 135)

\section{Coscinodiscus Granii GougH.}

Very common, in winter and spring, inside and outside the inlet. Neritic, north-temperate and boreal species. (YAMAZI, 1959, p. 24, 136)

Coscinodiscus Janischii A. SchMIDT

Rare, in warm seasons, widespread form.

\section{Coscinodiscus lineatus EHRENBERG}

Rare, off Sirahama, inside the bay, from winter to early summer, widespread form.

Coscinodiscus marginatus EHRENBERG

Not very common, from autumn to early summer, widely distributed. (YAMAZI, 1959, p. 136)

\section{Coscinodiscus nitidus GREGORY}

Rare, inside the bay, in spring and early summer, neritic species.

\section{Coscinodiscus oculus-iridis EHRENBERG}

Not common in the bay, chiefly in winter and spring, oceanic but frequently neritic. (Y AMAZI, 1959, p. 134)

\section{Coscinodiscus perforatus EHRENBERG}

Very rare, outside the bay, in winter season, widespread temperate form. (YAMAzI, 1959, p. 134)

\section{Coscinodiscus radiatus EHRENBERG}

Rare, inside and outside the bay, in cold season. Oceanic and neritic, temperate species. (YAMAZI, 1959, p. 136, 207, 214)

Coscinodiscus stellaris ROPER

Rare, in the bay in autumn. Oceanic, widespread species. (YAmAzI, 1959, p. 22, 214)

\section{Coscinodiscus wailesii GRAN \& ANGST}

One of the most abundant diatoms in winter, outside and inside the bay, northerly distributed species. (YAMAZI, 1959, p. 135)

\section{Coscinodiscus sp.}

\section{Ethmodiscus Gazellae (JANISCH) HustedT}

Rare, in tow-netting, in open sea water outside the inlet, in spring and early summer. Oceanic, tropical species. (YamazI, 1959, p. 156)

\section{Hemidiscus cuneiformis WALLICH}

Very rare, outside the bay, in summer and autumn. Oceanic, tropical or subtropical form. (YAMAZI, 1959, p. 23, 156)

\section{Planktoniella sol (WALlich) SchütT}

Rare, found occasionally in spring and summer, chiefly outside the bay. Oceanic tropical species. (YAMAZI, 1959, p. 34, 201)

\section{Family 3. Thalassiosiraceae}

\section{Lauderia borealis GRAN}

Not very common, in spring and summer. Neritic, widely distributed, temperate species.

Lauderia flaccida (CAST.) Péragallo

Inside the bay. (IKARI, MS.) 


\section{Lauderia gracialis GRUN.}

Very rare, found in winter in the bay. Neritic, north-temperate species.

Schröderella delicatula (PÉRAgALlo)

Rare in the bay, in spring and summer. Neritic, temperate species.

Thalassiosira condensata (CLEVE)

Thalassiosira decipiens (GRUN.)

Very rare, found occasionally in winter and early spring. Neritic, north-temperate species. (YAMAZI, 1959, p. 208)

\section{Thalassiosira gravida CLEVE}

Rare, found in winter and early spring. Neritic but frequently oceanic, north-temperate species. (YAMAZI, 1959, p. 208)

\section{Thalassiosira rotula MEUNIER}

Not common, outside and inside the inlet. Neritic, temperate and south-temperate species. (Y AMAZI, 1959, p. 48)

\section{Thalassiosira subtilis (OSTENFELD)}

Very common in the bay, chiefly in coldest season. North-temperate, oceanic but frequently neritic species. (YAMAZI, 1959, p. 46)

\section{Family 4. Skeletonemaceae}

\section{Skeletonema costatum (Greville) Cleve}

Most abundant inside the bay, in almost all season. Eurythermal and euryhaline, neritic, widely distributed in all seas. (Y AMAZ1, 1959, p. 40, 132)

\section{Stephanopyxis palmeriana (GREv.) Grunow}

Fairly common, inside and outside the bay. Neritic, warm-water species. (YAMAZI, 1959, p. 40,132$)$

\section{Stephanopyxis turris (GREvILLE)} pl. 4)

Very rare, in winter and spring, temperate and subtropical species. (Y AMAzI, 1959, color

\section{Family 5. Leptocylindraceae}

\section{Dactyliosolen antarcticus CASTRACANE}

Rare, in winter and spring, outside the bay. Oceanic, temperate species. (YAMAzI, 1959, p. 40)

Dactyliosolen mediterraneus PÉRAGallo [ $=$ D. tenuis (Cl.) Gran]

Common in the bay, chiefly in summer and autumn. Neritic, sporadically oceanic, widely distributed species. (YAMAZI, 1959, p. 216)

Guinardia flaccida (CAstracane) Péragallo

Common in the bay, in summer and autumn. Neritic south-temperate species. (Yamazd, 1959, p. 40)

\section{Leptocylindrus danicus Cleve}

Common in inner part of the bay, in autumn and winter. Neritic, temperate or northtemperate, widespread species. (YAMAZI, 1959, p. 40) 


\section{Family 6. Corethronaceae}

\section{Corethron hystrix Hensen $[=C$. criophilum CASTR. $]$}

Fairly common but never abundant, in winter. Oceanic, north-temperate species. (YAMAZI, 1959, p. 206)

Corethron pelagicum BRUN

Rare, in open water, outside the bay, from early summer to autumn. Oceanic, warmwater form. (YAMAZI, 1959, p. 156)

\section{Suborder SOLENIINEAE}

\section{Family 7. Rhizosoleniaceae}

\section{Rhizosolenia acuminata (PÉRAG.) GRAN}

Fairly common but not abundant in open water outside, from summer to autumn. Oceanic, subtropical or temperate species.

Rhizosolenia alata BRIGHTWELL

Common, in spring and autumn. Oceanic, sporadically neritic, temperate species. (YAMAzI 1959, p. 32, 206)

\section{Rhizosolenia alata f. gracillima (Cleve) GRUNOW}

Common in the bay, in spring and summer, neritic, temperate species.

Rhizosolenia alata $f$. indica (PÉRAG.) OSTENFELd

Common, sometimes abundant, in warm season of summer and autumn. Oceanic, warmwater form. (YAMAzI, 1959 p. 204)

\section{Rhizosolenia Bergonii PÉragallo}

Rare, outside the bay, in summer and autumn. Oceanic, south-temperate or subtropical warm-water species. (YAMAZI, 1959, p. 157, 204)

\section{Rhizosolenia calcar avis $M$. SchulTzE}

Common or very abundant, in summer and autumn. Oceanic, tropical or subtropical warm-water species. (YAMAZI, 1959, p. 63, 157, 204)

\section{Rhizosolenia Clevei Ostenfeld}

Very rare in summer and autumn. Oceanic, warm-water species.

Rhizosolenia cylindrus CLEVE

Rarer in warm season. Neritic, tropical or subtropical form. (YAMAzI, 1959, p. 157)

Rhizosolenia delicatula CLEvE

Rarer in the bay, in warm season. Neritic, temperate species.

\section{Rhizosolenia hebetata (BAILEY) GRAN f. semispina (HENSEN) GRAN}

Common in warm season, chiefly in summer and autumn. Oceanic, warm-water species. (YAMAzI, 1959, p. 217)

\section{Rhizosolenia imbricata BRIGHTWELL}

Rarer in the bay, in summer and autumn. Oceanic, warm-water species.

Rhizosolenia imbricata var. Schrubsolei CLEvE

Rare in the bay, in spring and summer. Neritic, north-temperate species.

\section{Rhizosolenia robusta NORMAN}

Common in warm season, inside and outside the bay. Oceanic, widely distributed, especially in warm water. (YAMAZI, 1959, p. 157, 203) 


\section{Rhizosolenia setigera BRIGHTWELL}

Commonest from early spring to early summer. Neritic, north-temperate or temperate species. (YAMAZI, 1959, p. 157)

\section{Rhizosolenia stolterfothii PÉRAGALLO}

Very common, from spring to summer, neritic sometimes oceanic, very widespread, southtemperate or tropical species. (YAMAZI, 1959, p. 42)

Rhizosolenia styliformis BRIGTWELL

Common from spring to autumn. Oceanic, temperate and north-temperate species.

Rhizosolenia styliformis var. latissima BRIGHTWELL

Commonest in early summer but frequently in warm season. Oceanic, temperate and north-temperate species. (YAMAZI, 1959, p. 204)

\section{Suborder BIDDULPHIINEAE}

\section{Family 8. Bacteriastraceae}

Bacteriastrum comosum PAVILLARD

IKARI (1927); YAMAZI, (1959, p. 160)

Bacteriastrum comosum var. hispida (CASTR.) SCHRÖDER

IKARI (1927); YAMAZI, (1959, p. 160)

Bacteriastrum delicatulum CIEVE

Common in the bay, in summer and autumn. Oceanic, temperate species.

\section{Bacteriastrum elongatum CLEVE}

Rare, in summer and autumn. Oceanic, temperate species. (Ikari, 1927)

Bacteriastrum elongatum CLEVE var. diversum IKARI

IKARI (1927).

Bacteriastrum hyalinum LAUDER

Common in the bay, in almost all seasons. Neritic, littoral form. (YAMAZI, 1959, p. 64)

Bacteriastrum hyalinum LAUdER var. princeps (CASTRACANE) IKARI

Nertic, warm-water species, common.

Bacteriastrum mediterraneum PAVILLARD

IKARI (1927).

Bacteriastrum minum KARSTEN

In summer, rarer in the bay (IKARI, 1927).

Bacteriastrum biconicum PAVILLARD

Rare in the bay (IKARI, 1927).

Bacteriastrum varians LAUDER

Commonest Bacteriastrum in our region, in almost all seasons, sometimes in swarms inside. Neritic and littoral, widespread form.

\section{Family 9. Chaetoceraceae}

\section{Chaetoceros (Phaeoceros) atlanticus CLEVE}

Rarer in the bay, in coldest season. Oceanic, typically northern, arctic and boreal form. (YAMAZI, 1959, p. 205, 213) 
Chaetoceros (Phaeoceros) atlanticus var. neapolitanus (ScIröDER) HUSTEDT

Oceanic southern, temperate or subtropica form. Rarer, found occasionally in summer and autum. (YAMAZI, 1959, p. 157, 203)

Chaetoceros (Phaeoceros) coarctatus LAUDER

Rather common but never abundant. Oceanic, subtropical or tropical form. (YAMAzI, 1959, p. 103, 158)

Chaetoceros (Phaeoceros) castracanei KARSTEN

Oceanic form. (IKARI, 1926)

Chaetoceros (Phaeoceros) dadayi Pavillard

Very rarely found in warm season, in open sea water off Sirahama. Oceanic, tropical form.

Chaetoceros (Phaeoceros) danicus Cleve

Rarer in littoral zone. North-temperate species.

Chaetoceros (Phaeoceros) densus Cleve

Commonly found in cold season. Widespread, northern species.

Chaetoceros (Phaeoceros) denticulatum LAUDER

Rare in the bay, in open sea water off Sirahama. Oceanic, subtropical species. (YAMAzI, 1959 , p. 158)

Chaetoceros (Phaeoceros) Eibenii Grunow

Fairly common, in open sea water. Neritic, temperate species. (YAMAzI, 1959, p. 158)

Chaetoceros (Phaeoceros) indicum KARSTEN $[=$ C. nanodenticulatum OKAMURA $]$

Chaetoceros (Phaeoceros) okamurai IKARI

Rarely found in the bay. (IKARI, 1928)

Chaetoceros (Phaeoceros) pendulus KARSTEN

Rarely found in open sea water, in summer and autumn. Oceanic, temperate or subtropical form.

Chaetoceros (Phaeoceros) peruvianus BRIGHTWELL

Commonly found in open water almost in warm season. Oceanic, temperate or tropical form. (YAMAZI, 1959, p. 159)

Chaetoceros (Phaeoceros) pseudodichaeta IKARI

(IKARI (1926).

Chaetoceros (Phaeoceros) rostratus LAUDER

Very rare in the bay, in warm season. Oceanic, subtropical species.

Chaetoceros (Phaeoceros) tetrastichon CLEVE

Very rarely found, occasionally in warm season, in open sea water. Oceanic, subtropical and south-temperate species.

Chaetoceros (Hyalochaete) affinis LAUder. [=C. Schüttii Cleve; C. javanicum Cleve] Commonest Chaetoceros in our region, throughout the year, from spring to autumn. Neritic, south-temperate but frequently widespread. (YAMAzI, 1959, p. 139)

Chaetoceros (Hyalochaete) anastomosans GRUNOW

Rare, occasionally met with in warm season. Neritic, south-temperate species.

Chaetoceros (Hyalochaete) brevis ScHütT 140)

Rare, in warm season. Neritic, south-temperate warm-water species. (YAMAzI, 1959, p. 


\section{Chaetoceros (Hyalochaete) compactum IKARI}

Rare, in the innermost part of the bay, in summer. Neritic and littoral form. (YAMAZI, 1959, p. 142)

Chaetoceros (Hyalochaete) compressus LAUDER

One of the most abundant species, everywhere, throughout the year, especially in spring and autumn. Neritic, from boreal to south temperate. (YAMAzI, 1959, p. 138)

\section{Chaetoceros (Hyalochaete) constrictus GRAN}

Common in winter and spring. Neritic, north-temperate, cold water species. (YAMAZI, 1959, p. 139)

\section{Chaetoceros (Hyalochaete) costatus PAvILLARD}

Rare, in late summer and autumn, inside the bay. Neritic, warm-water subtropical species. (YAMAZI, 1959, p. 140)

\section{Chaetoceros (Hyalochaete) curvisetus CLEVE}

Very common, in the innermost part of the bay. Neritic, south-temperate species. (YAMAzI, 1959, p. 203)

\section{Chaetoceros (Hyalochaete) debilis Cleve}

Common but not abundant, in cold seasons. Neritic, north-temperate species. (YAMAzI, 1959, p. 142)

\section{Chaetoceros (Hyalochaete) decipiens Cleve}

Very abundant, chiefly in winter and spring, inside and outside the bay, one of the most abundant Chaetoceros. Oceanic and neritic widely distributed, northern form. (YAMAzI, 1959, p. 137)

\section{Chaetoceros (Hyalochaete) decipiens f. singularis GRAN}

North-temperate species.

Chaetoceros (Hyalochaete) didymus EHRENBERG

Common in spring and summer. Neritic, south-temperate species. (YAMAZI, 1959, p. 137)

Chaetoceros (Hyalochaete) didymus var. protuberans (LAUDER) GRAN \& YENDO Very common in cold seasons. Euryhaline and eurythermal species.

\section{Chaetoceros (Hyalochaete) didymus var. anglica (GRUNOW) GRAN}

Very common, in warm seasons than var. protuberans, from early summer to autumn. Eurythermal form. (YamazI, 1959, p. 138)

\section{Chaetoceros (Hyalochaete) distans CLEVE}

Common in the inlet waters, in summer. Neritic, warm-water species. (YAMAzI, 1959, p. 18,140 )

\section{Chaetoceros (Hyalochaete) diversus Cleve}

Very rare, in outside waters, in summer and autumn. Neritic, tropical and subtropical species. (Y AMAZI, 1959, p. 24, 159)

\section{Chaetoceros (Hyalochaete) Frichei HustedT}

In the inlet waters. (IKARI, 1926)

Chaetoceros (Hyalochaete) hispidum BRIGHTwELL

Warm-water species (IKARI, 1926)

\section{Chaetoceros (Hyalochaete) laciniosus SCHÜTT}

Fairly common, in summer, inside the bay. Neritic, south-temperate and subtropical species. 


\section{Chaetoceros (Hyalochaete) lauderi RALFS.}

Not common, chiefly in summer. Neritic, warm-water species. (YAMAzI, 1959, p. 137)

\section{Chaetoceros (Hyalochaete) Lorenzianus GRUNOW}

Very common almost everywhere, from early summer to autumn. Neritic, subtropical and temperate, widespread form. (YAMAZI, 1959, p. 25, 137)

Chaetoceros (Hyalochaete) messanensis CASTRACANE [-C. furca Cleve]

Found occasionally in open sea water outside the bay, in summer and autumn. Oceanic tropical and subtropical species. (YAMAzI, 1959, p. 159)

\section{Chaetoceros (Hyalochaete) paradoxus CLEvE}

Common inside, in warm season. Neritic, subtropical, warm-water species. (YAMAzI, 1959, p. 140)

\section{Chaetoceros (Hyalochaete) pelagicus CLEvE}

Common inside the bay, in warm season. Neritic, temperate form.

\section{Chaetoceros (Hyalochaete) pseudocurvisetus MANGIN}

Not common, in the inlet, in warm season. Neritic. Tropical and subtropical species. (YAMAZI, 1959, p. 141)

\section{Chaetoceros (Hyalochaete) radicans SCHÜTT $[=C$. scolopendra CLEVE)}

Very abundant in the inlet waters, throughout the year, especially in spring and summer. Neritic, north temperate species. (YAMAZI, 1959, p. 142)

\section{Chaetoceros (Hyalochaete) seiracanthus GRAN}

Rare, in winter and spring, inside the inlet. Neritic and bittoral zone, north-temperate form but widely distributed. (YAMAZI, 1959, p. 64, 141)

Chaetoceros (Hyalochaete) setoensis IKARI

Common, inside the inlet. Neritic, warm-water form.

\section{Chaetoceros (Hyalochaete) siamensis OSTENFELD} p. 139)

Rare, in the inlet, from summer to autumn. Neritic, warm-water species. (YAMAzI, 1959,

\section{Chaetoceros (Hyalochaete) socialis LAUDER}

Common and often very abundant inside the bay, in winter and early spring. Neritic, north-temperate, cold-water species. (YAMAZI, 1959, p. 48)

Chaetoceros (Hyalochaete) subsecundus (GRAN) HuSTEDT $[=C$. diadema (EHRENBERG) Creve

Common from winter to spring, inside the inlet. Neritic. Cold water species but widespread. (Y AMAZI, 1959, p. 39, 141)

\section{Chaetoceros (Hyalochaete) tortissimus GRAN}

Very rare, in the inlet, in the cold season during winter and spring. Neritic, northtemperate species. (YAMAZI, 1959, p. 142)

\section{Chaetoceros (Hyalochaete) Van Heurckii GraN}

Common, inside the bay, from winter to early spring. Neritic, widespread, probably confused with Ch. constrictus. (YAMAZI, 1959, p. 64, 139)

\section{Chaetoceros (Hyalochaete) Weissflogii ScHüTT}

Not common inside the bay, especially in summer and autumn. Neritic, warm-water form. (YAMAZI, 1959, p. 137) 


\section{Family 10. Biddulphiaceae}

\section{Bellerochea malleus (Brightwell) VAN HeURCK}

Very rare, in the bay, and in the open water, in summer. Neritic, warm-water species. (YAMAZI, 1959, p. 151)

\section{Biddulphia aurita (LYNGB.)}

Rare in the bay, in cold season. Neritic and littoral, widely distributed, but northern species. (YAMAZI, 1959, p. 207)

Biddulphia longicruris GREvILLE var. japonica GRUNOW

Rare in the bay, in summer and autumn. Neritic. Warm-water species. (YAMAZI, 1959, p. 150)

\section{Biddulphia mobiliensis BAILEY}

Not very common, in summer season. Neritic, widely distributed, truly planktonic, temperate and south-temperate species. (YAMAZI, 1959, p. 149)

\section{Biddulphia pulchella GRAY $[=B$. biddulphiana BAYER $]$}

Occurs in plankton accidentally (tichopelagic) in spring and summer but a bottom form. (YAMAZI, 1959, p. 149)

\section{Biddulphia sinensis Greville}

Found occasionally in warm seasons, outside the bay. Oceanic. Warm-water species, but sometimes common in littoral. (YAMAZI, 1959, p. 65, 150)

\section{Biddulphia Tuomeyi (BAIL)}

Very rare, widely distributed, neritic form.

\section{Cerataulina Bergonii H. PÉragallo}

Rare in the inlet, in summer and autumn. Neritic, south-temperate species. (YAMAZI, 1959, p. 150)

\section{Cerataulina compacta OSTENFELD}

Rare, in the open sea water at the mouth, in summer and autumn. Neritic. south-temperate and subtropical species.

\section{Ditylum Brightwelli (WeST) GRUNOW}

Common in the inlet, in autumn and winter. Neritic, south-temperate species. (YAMAZI, 1956, p. 63)

\section{Ditylum sol Grunow}

Common but not abundant, in the open sea water, in summer and autumn. Neritic, south-temperate and subtropical species. (YAMAZI, 1959, p. 23, 63)

\section{Hemiaulus Haucki Grunow}

Very rare, found occasionally in open sea water, in summer and autumn. Oceanic or neritic, temperate and subtropical form.

\section{Hemiaulus membranaceus CLEVE}

Very rare, in the offshore water near the mouth of the bay, in warm season. Probably oceanic, tropical species.

\section{Hemiaulus sinensis GrEviLLE}

Not very common, in open sea water outside the bay, from summer to autumn. Neritic. South-temperate or subtropical form. (YAMAZI, 1959, p. 204)

\section{Lithodesmium undulatum EHRENBERG}

Very rare, in summer season. Neritic, south-temperate species. 


\section{Triceratium favus EHRENBERG}

Very rare, occasionally in warm seasons. Tichopelagic, widely distributed in the bay. (YAMAZI, 1959, p. 151)

Triceratium gibbosum BAIL

Common inside in the bay, in spring. Neritic, tichopelagic species, widely distributed. (YAMAZI, 1959, p. 149)

Triceratium reticulum EHRENBERG

Very rare, in the bay, in warm seasons. (YAMAZI, 1959, p. 151)

Triceratium revale $A$. SCHMIDT

Very rare, in spring and autumn, neritic, tichopelagic, widely distributed. (YamAzI, 1959, p. 151)

\section{Family 11. Eucampiaceae}

\section{Climacodium biconeavum CLEVE}

Very rare, in the open sea water, in summer and autumn. Oceanic, south-temperate and tropical species. (YAMAZI, 1959, p. 39, 160)

\section{Climacodium Frauenfeldianum GRUNOW}

Very rare, in the open sea water, outer part of the bay, in warm season. Oceanic, tropical or subtropical species. (Y AMAZI, 1959, p. 41, 203)

Eucampia cornuta (Cleve) Grunow

Rarely found in the open sea water, in warm season. Neritic, tropical species. Warmer water species than E. zoodiacus.

\section{Eucampia zoodiacus EHRENBERG}

Abundant, sometimes in swarms, from autumn to spring. Neritic, south-temperate form. (YAMAZI, 1959, p. 42, 133)

\section{Streptotheca indica KARSTEN}

Very rare, in open sea water, in summer and autumn. (YAMAZI, 1959, p. 39, color pl. 4) Streptotheca thamensis ScHRUBSOLE

Very rare, in the inlet, from autumn to spring. Neritic, north-temperate species.

\section{Order PENNALES}

Suborder ARAPHIDINEAE

\section{Family 12. Fragilariaceae}

\section{Asterionella japonica CLEVE}

Common in the bay, in winter and spring, rare in summer. Neritic, south-temperate, widely distributed species. (YAMAZI, 1959, p. 44)

\section{Asterionella kariana GRUNOW}

Rarer in the bay, in cold season. Neritic, cold-water species.

\section{Asterionella notata GRUNOW}

Rarer in the bay, in cold season. (YAMAZt, 1959, p. 147) 
Thalassionema (=Thalassiothrix) nitzschioides GRUNOW

Present throughout the year common inside the bay, especially in summer and autumn. Neritic and littoral, widepread, temperate species. (YAMAZI, 1959, p. 49)

Thalassiothrix Frauenfeldii GRUNOW

Very abundant in neritic, littoral and oceanic zone. Occurs in almost all seasons, especially in summer and autumn. South-temperate form. (YAMAZI, 1959, p. 44, 133)

Thalassiothrix longissima CleVE \& GRUN.

Common, in the bay, especially from autumn to spring. Oceanic, north-temperate and boreal species, widespread. (YAmAzI, 1959, p. 32)

\section{Family 13. Tabellariaceae}

\section{Climacosphenia moniligera EHRENBERG}

Littoral, in innermost region, abundant in warm seasons. Tichopelagic form. (YAMAZI, 1959, p. 152)

Climacosphenia sp.

Licmophora abbreviata AGARDH $[\because L$. Lyngbyei (KüTZ.) GRAN]

Littoral, occurs in plankton accidentally but a bottom species. Widely distributed. (YAMAZI, 1959, p. 146)

Licmophora flabellata (GARM.) AGARDH.

Common in the inlet waters, in spring and summer, neritic, tichopelagic. (YAMAZI, 1959, p. 145)

\section{Rhabdonema adriaticum KüTZING}

Ubiquitous, temperate-water species. (YAMAZI, 1959, p. 41, 151)

Striatella unipunctata (LYN.) AGARDH 148)

Common in the innermost area. Tichopelagic, temperate species. (YAMAZI, 1959, p. 41,

\section{Family 14. Achnanthaceae}

\section{Achnanthes longipes AGARDH}

Tichopelagic, littoral, north-temperate species. (YamAzI, 1959, p. 18)

Cocconeis scutellum EHREnBERG

Very rare, often found in plankton but a bottom form.

\section{Suborder BIRAPHIDINEAE}

\section{Family 15. Naviclaceae}

Amphora laevis Greg. [ - A. nobilis FlÖGEL]

Very rare, in inlet waters, littoral, tichopelagic species. Rare in warm season. (YAMAZI, 1959, p. 148)

\section{Pleurosigma angulatum (QUEK.) W. SMIth}

Occurs in plankton accidentally (tichopelagic), widespread, neritic and littoral species, very rare. (YAMAZI, 1959, p. 155) 
Pleurosigma intermedium W. SMITH

Very rare, in inlet waters, in summer season, tichopelagic, littoral species. (YamazI, 1959, p. 154)

\section{Family 16. Epithemiaceae}

Denticula sp. 1

Very rare, in the inner part of the inlet.

Denticula sp. 2

(YAMAZI, 1959, p. 207, 208)

\section{Family 17. Nitzschiaceae}

\section{Nitzschia closterium W. SMITH}

Common, in the inlet waters, throughout the year, frequently in the plankton, widely distributed, euryhaline species. (YAMAZI, 1959, p. 153)

\section{Nitzschia delicatissima CLEVE}

Common in the inlet waters, from autumn to spring, ubiquitous but northern species.

Nitzschia longissima (BRÉB.) GRAN

Rare, in the bay water, in spring and summer. Littoral, tichopelagic species. Never in large numbers. (YAMAZI, 1959, p. 153)

Nitzschia longissima var. reversa W. SMrTH

Very rare, in bay water in summer to winter. Tichopelagic, littoral species.

Nitzschia pacifica CUPP

Rare in the bay, in spring and summer, neritic, sporadically oceanic, temperate-water species. Present with $N$. seriata. (YamazI, 1959, p. 45, 133, 153)

Nitzschia (=Bacillaria) paradoxa GMELIN

Rare in inlet waters, in spring and summer. Widespread, euryhaline, littoral, marine and brackish-water, tichopelagic species. (YAMAZI, p. 45, 133, 153)

\section{Nitzschia seriata $\mathrm{C}_{\mathrm{LEVE}}$}

Very common, all the year round, inside and outside the bay, ubiquitous. Euryhaline and eurythermal, neritic and littoral species. (Yamazr, 1959, p. 133)

Nitzschia sigma (KüTZ.) W. SMITH

Very rare, in the inlet waters. Widespred, tichopelagic species. (YAMAZI, 1959, p. 153)

\section{Suborder SURIRELLINEAE}

\section{Family 18. Surirellaceae}

\section{Campylodiscus undulatus Grev.}

Very rare, in the inlet waters. Littoral, tichopelagic species.

Surirella cuneata A. S.

Very rare, in spring and autumn. Littoral, tichopelagic species. 


\section{Phylum PROTOZOA}

\section{Class MASTIGOPHORA \\ Order CHRYSOMONADINA}

\section{Dictiocha fibula (EHRENBERG)}

Very common, centrifuged, in the inner part of the bay. (YamazI, 1959, p. 128)

\section{Dictiocha fibula var. stapedia (HAECKEL) LEMMERMANN}

Occasionally common, centrifuged, in the inner part of the bay. Found in Sept. (IKARI, MS)

Distephanus speculum (EHRENBERG)

Rare, centrifuged, inside the bay. (YAMAzI, 1959, p. 212; IKARI, MS)

Distephanus speculum var. pentagonum SCHULZ

Rare, centrifuged in the innermost part of the bay. Found in October. (IKARI, MS)

Distephanus speculum var. polyactis (EHRENBERG) LEMMERMANN

Rare, centrifuged, in the innermost part of the inlet, in July. (IKARI, MS)

Mesocera polymorpha var. bioctonaria (EHRBG.) LEMMERMANN

Rare, centrifuged, inside the bay. Found in October. (IKARI, MS)

\section{Order DINOFLAGELLATA}

Family 1. Noctilucidae

\section{Noctiluca scintillans MACARTNEY}

Very common, throughout the year, almost everywhere, especially in the innermost area of inlets, sometimes very abundant in swarms from early winter to spring. Ubiquitous species. (YAMAZI, 1959, p. 52, 62, 118)

\section{Family 2. Phytodinidae}

\section{Pyrocystis fusiformis MurRay}

Very rare, found in warm seasons, in the open sea water outside the bay. Oceanic, warm-water form. (YamAzI, 1959, p. 172)

Pyrocystis hamulus Cleve var. inaequalis SCHRÖDER

Very rare, in summer, outside the bay. Oceanic, warm-water species. (YAMAZI, 1959, p. 61,172 )

Pyrocystis hamulus CLeve var. semicircularis SCHRöder

Very rare, in open sea water outside the bay. Oceanic, warm-water species.

\section{Pyrocystis lunula SchÜTT}

Rare, in open-sea water, in late spring and summer. Oceanic, widespread species.

\section{Pyrocystis noctiluca MurRay}

Fairly common, in warm season, in open sea waters. Oceanic, ubiquitous, warm-water species. (YAMAZI, 1959, p. 52, 61, 123, 172) 


\section{Family 3. Prorocentridae}

\section{Prorocentrum micans Ehrenberg}

Rare, in the innermost part of the inlet but sometimes common, centrifuged, neritic and littoral form. (YAMAz1, 1959, p. 161)

\section{Family 4. Peridiniidae}

\section{Amphysolenia bidentata SCHRÖDER}

Occasionaly caught outside the bay, in summer and autumn. Oceanic, warm-water species. (YAMAZI, 1959, p. 162)

\section{Amphysolenia thrinax SCHÜTT}

Rare, in open sea outside the bay, in summer and autumn. Oceanic, warm-water species. (YAMAZI, 1959, p. 162)

\section{Blepharocysta splender maris EHRENBERG}

Very rare but occasionally found in open sea water near the mouth, in summer and autumn. Oceanic, warm-water species.

\section{Ceratium belone CLEVE}

Rare, in the mouth of the bay, in warm season. (YAMAzI, 1959, p. 166)

Ceratium candelabrum (EHRENBERG) STEIN

Very rare, found outside the bay, in summer and autumn. Warm-water, oceanic species. (Y AMAZI, 1959, p. 171).

Ceratium candelabrum var. dilatatum (GOURR.) JÖRGENSEN

Very rare, in open sea water outside, in warm seasons. (YAMAZI, 1959, p. 62)

\section{Ceratium carriense Gourret}

Rare, at the mouth of the bay, in summer and autumn. Oceanic, warm-water species, in Kurosio Current. (YamazI, 1959, p. 167)

Ceratium carriense f. ceylanicum (B. SCHRÖD.) JÖRGENSEN

Outside, rare, in warm water season. Oceanic, in warm Kurosio Current. (YAMAzI, 1959, p. 28,168 )

\section{Ceratium contortum (Gourr.) Cleve}

Very rare, in open sea water, warm seasons. Oceanic species.

Ceratium defiexum (KoFOID) JÖRGENSEN

Very rare, in open sea outside the bay, in summer and autumn. Oceanic, warm-water species. (YAMAZI, 1959, p. 167)

\section{Ceratium extensum (GouRreT) Cleve}

Very rare, open-sea water, summer and autumn. Ubiquitous, warm-water species.

Ceratium furca (Ehrenterg) DuJARdin

Very common, found almost everywhere, especially inside the bay, in spring and summer. Widespread species. (YamAZI, 1959, p. 128, 165).

\section{Ceratium furca eugrammum JöRGENSEN}

Common, inside the bay, spring and summer.

Ceratium fusus (Ehrenberg) Dujardin

Common, inside and outside the inlet, in summer. (YAMAZI, 1959, p. 32, 166) 


\section{Ceratium fusus seta (EHRENBERG) JörgenSEN}

Common, inside and outside the bay, in summer (YAMAZI, 1959, p. 166)

\section{Ceratium gibberum GourReT} p. 170)

Outside the inlet, rare, in summer and autumn. Warm-water species. (YAMAzI, 1959,

Ceratium gibberum $f$. sinistrum GoURRET

Outside the inlet, rare, in summer and autumn. (YAMAZI, 1959, p. 43)

\section{Ceratium gravidum GourReT}

Very rare, found outside the inlet, in summer and autumn. Oceanic, warm-water species. (YAMAZI, 1959, p. 36)

Ceratium incisum (KARSTEN) JÖRGENSEN

Very rare, found in the open sea water off the inlet, in summer and autumn. Warm water species. (YAMAZI, 1959, p. 166)

Ceratium inflexum (Gourret) KofoId

In open sea water, very rare, in summer and autumn. Offshore-water form.

Ceratium intexmedium (Jörg.) JöRGENSEN

Found almost everywhere, throughout the year, 'especially in summer and autumn. (YAMAZI, 1959 , p. 168,169 )

\section{Ceratium Kofoidi JÖRGENSEN}

Rare, in open sea water near the mouth, in summer and autumn. Warm water form. (YAMAZI, 1959, p. 165)

Ceratium macroceros (Ehrenberg) Cleve

Occasionally common. outside the bay, in summer and autumn. Warm water form. (YAMAZI, 1959, p. 168).

\section{Ceratsum massiliense (GOURRET) JÖGENSEN}

Common, open sea water near the mouth, in summer and autumn. (Y AMAZI, 1959, p. 169)

Ceratium molle KOFOID p. 169)

Rare, outside the inlet, in warm season. Oceanic, warm-water species. (YAMAzI, 1959,

Ceratium palmatum var. ranipes (CLEVE) JÖRGENSEN

Very rare, found occasionally outside the bay, in warm seasons. (YAMAZI, 1959, p. 31)

Ceratium pentagonum GoURRET

Sometimes in numbers in open sea waters, in warm season.

Ceratium pennatum KOFOID

Rare, in open sea water, warm-water form. (YAMAZI, 1959, p. 166)

Ceratium platycorne V. DADAY

Very rare, in open water, summer and autumn, oceanic, warm-water species.

Ceratium pulchellum SCHRÖDER

Rare, outside the inlet, in summer and autumn. Oceanic, warm-water species.

Ceratium reticulum (POCHET) f. contortum (LEMM.)

Very rare, in summer, warm water species.

Ceratium strictum (OKamura et Nishikawa) Kofoid

Outside the bay, very rare, in summer and autumn. Warm-water form. (YAMAZI, 1959, p. 166) 


\section{Ceratium sumatranum (KARSTEN) JöRGENSEN}

Fairly common, outside the bay, in summer and autumn, warm-water species. (YAMAzI, 1959, p. 43,62 )

\section{Ceratium sumatranum f. angulatum JörgenSEN}

Rare, outside the bay, in summer and autumn. Oceanic, warm-water species. (YAMAzI, 1959, p. 170)

Ceratium tenue (OSTF. et SCHM.) JörgenSEN

Outside the inlet, warm water species.

Ceratum tenue var. buceros (ZACHARIAS) JÖRgENSEN

Warm water species. (YAMAZr, 1959, p. 168)

Ceratium trichoceros (EHRENBERG) KOFOID

Very common at times in swarm, in warm seasons. (YAMAZI, 1959, 168)

Ceratium tripos (O. F. MÜller) Nitsch.

Very common, inside and outside the inlet, in summer and autumn. Widely distributed (YAMAZI, 1959, p. 171)

\section{Ceratium vultur Cleve}

Very rare, in open sea waters near the mouth, in summer. Oceanic, warm-water species. (YAMAZI, 1959, p. 169)

Ceratium sp. 1

(YAMAZI, 1959, p. 166)

Ceratium sp. 2

(YAMAZI, 1959, p. 170)

Ceratocoris horrida STEIN

Fairly common, in open sea water, in summer and autumn. Oceanic, warm-water species.

\section{Dinophysis hastatus STEIN}

Very rare, in open water outside the bay, in summer and autumn.

\section{Dinophysis homunculus STEIN}

Rare, in open sea outside the bay, in warm seasons. YAMAZI, 1959, p. 161)

Dinophysis homunculus $f$. pedunculatus SCHMIDT

Occasionally outside the bay, summer and autumn. Warm-water species.

Dinophysis ovum SCHÜTT

Early spring and summer, very rare in inner part of the bay.

Diplopsalis lenticula BerGH

Rare, found inside and outside the bay, in early spring and summer. (YAMAzI, 1959, p. 163)

Glenodinium danicum PaUlsen?

Common at times, in summer, inside the inlet. (YAmAzi, 1959, p. 128)

Goniaulax polygramma STEIN

Rare, in the inlet. Warm-water, neritic species.

Goniodoma polyedricum (POUCHET)

Very rare, in open sea water, in summer. Oceanic, warm-water species.

\section{Orinthocercus magnificus STEIN}

Only once found outside the bay, in summer, oceanic, warm-water species. (YAMAZI, 1959, p. 161) 


\section{Orinthocercus splendicus STEIN}

Very rare, found occasionally in summer. Oceanic, warm-water species.

Oxytoxum milneri MürR. et WHITT.

Very rare, in the open sea, in summer. Tropical, oceanic form.

Oxytoxum scolopax STEIN

Very rare, in open sea water, in summer. Oceanic, tropical species.

Peridinium conicum (Gran) Ostenfeld et Schmidt

Common, inside and outside the bay, widespread. (YAMAZI, 1956, p. 163)

\section{Peridinium crassipes KOFOID}

Fairly common, in open-sea water outside and inside the bay, from winter to early summer.

\section{Peridinium depressum BAILEY}

Common, in open sea water outside the bay, in summer and autumn, widespread. (YAMAZI, 1959 , p. 53, 163)

\section{Peridinium globulum STEIN}

Very rare, inside and outside the bay, in summer and autumn.

\section{Peridinium grande KOFOID}

Common, inside and outside the bay, widely distributed.

\section{Peridinium Granii Ostenfeld}

Rare, inside and outside, in summer and autumn.

\section{Peridinium longipes KARSTEN}

Very rare in open sea water, in summer and autumn. (Y.AMAZI, 1959, p. 161)

\section{Peridinium oceanicum VAnHöfFen var. oblongum AurIv.}

Common, in the innermost part of the bay, in summer and autumn. Neritic and littoral species. (YamAzx, 1959, p. 128, 164)

\section{Peridinium pallidum OSTENFELd}

Not very common in the bay, from early summer to autumn.

\section{Peridinium pentagonum GraN}

Not common, in spring and summer, inside and outside the bay. (YAMAZI, 1959, p. 164)

\section{Peridinium pyriforme PAULSEN}

Rarer, inside and outside the bay, in summer and autumn.

\section{Peridinium sphaericum OKAMURA}

Very rare, in the inner part, in summer and autumn.

Peridinium steinii Jörgensen

Rare, inside and outside the bay, in summer and autumn.

\section{Pyrophacus horologicum STEIN}

Common in the open sea, in warm season. Oceanic, tropical or subtropical species. (YAMAzI, 1959, p. 34)

\section{Triposolenia bicornis (KOFOID)}

Very rare, outside the bay, in summer. Oceanic, tropical species. 


\section{Class SARCODINA}

\section{Order FORAMINIFERA}

Globigerina bulloides D'ORBIGNY

Sometimes frequent, in summer and autumn. Oceanic, warm-water species. (YAMAZI, 1959 , p. 26)

Orbulina universa D'ORBIGNY

Very rare, outer part of the bay, in warm season. Oceanic, warm-water species.

Tretomphalus bulloides (D'OrBIGNY)

Very rare, only once found outside the inlet, in summer. Oceanic, warm-water species.

Order RADIOLARIA

Abyla sp.

(YAMAZI, 1959, p. 177)

Abylopsis sp.

(YAMAzI, 1959, p. 177)

Acanthochiasma sp.

(YAMAZI, 1959, p. 173)

Acanthometron pellucidum (J. MÜLLER)

(YAMAZI, 1959, p. 174)

Acanthonina crux Cleve

(YAMAZI, 1959, p. 173)

Amphilonche belonoides HAECKEL

Amphibelone sp.

Amphipule sp.

Anchylometra sp.

(YAMAZI, 1959, p. 173)

(IKARI, MS.)

Astroma sp.

(YAMAZI, 1959, p. 180)

(YAMAZI, 1959, p. 175)

Aulacantha scolimantha HAECKEL

(YAMAZI, 1959, p. 173)

Aulosphaera cruciata HAECKEL

Cladococcus sp.

(IKARI, MS.)

Coelodendrum sp.

(IKARI, MS.)

Colozoum amoeboides HAECKEL

(IKARI, MS.)

Colozoum inerme HAECKEL

(Y AMAZI, 1959, p. 47)

Cromyomma sp.

(YAMAZI, 1959, p. 174)

Diploconeus sp.

(IKARI, MS)

Drymosphaera polygonalis HAECKEL

(YAMAZI, 1959, p. 174)

Eusyringium sp.

(IKARI, MS.)

Gazelletta hexanema HAECKEL

Gazelletta sp.

Heliocladus sp.

(YAMAZI, 1959, p. 175)

Hexalonche sp.

(YAMAZI, 1959, p. 174)

Lychnocanium sp.

(YAMAZI, 1959, p. 202)

Lithophyllium sp.

(IKARI, MS.)

Octopyle sp.

(IKARI, MS.)

Polysolenia sp.

(YAMAZI, 1959, p. 202) 
Pterocanium sp.

Sphaerozoum geminatum HAECKEL

(YAMAZI, 1959, p. 46)

Sphaerozoum sp.

(IKARI, MS.)

Staurocantha sp.

(YAMAZI, 1959, p. 175)

Staurosphaera sp.

(YAMAZI, 1959, p. 174)

Tetraspyris sp.

(IKARI, MS.)

Trizone brandti PoP.

(YAMAZI, 1959, p. 175)

Zonidium sp.

(YAMAZI, 1959, p. 202)

\section{Order HELIOZOA}

Sticholonche zanclea (O. SCHRÖDER)

Very abundant, in the inner part of the inlet, throughout the year, especially in spring and autumn. Neritic and littoral, ubiquitous species. (YAMAZI, 1959, p. 26, 212)

\section{Class CILIOPHORA}

\section{Subclass CILIATA}

Order HOLOTRICHA

Suborder TINTINNOINEA

\section{Family 1. Tintinnidae}

\section{Leptotintinnus nordqvisti (BRANDT)}

Rare, inside and outside the bay, from early summer to autumn. Neritic, warm-water species. In October (IKARI, MS.)

\section{Family 2. Codonellidae}

Codonella inflata Koford et CAMPBELL

Warm water species. Found in September (IKARI, MS.)

Tintinnopsis aperta var. tocantinensis KOFOID et CAMPBELL

Rere, inside the bay, in warm seasons. Neritic, warm-water species. In October (IKARI, MS.)

\section{Tintinnopsis beroidea STEIN}

Very common, throughout the year, especially in spring and summer. Neritic, eurythermal, from tropical to boreal. (YAMAZI, 1959, p. 129)

Tintinnopsis cylindrica DADAY

Common, inside the inlet, in summer season. Neritic, warm-water form.

Tintinnopsis gracilis Koford et CAMPBELL

Rare, inside the inlet, in summer. Neritic, warm-water form. (YAMAzI, 1959, p. 129)

\section{Tintinnopsis karajacensis BRANDT}

Rare, inside and outside the bay, in warm seasons. Neritic, warm-water species. In September. (IK.ARI, MS.) 


\section{Tintinnopsis mortensenii SCHMIDT}

Rare, found occasionally in summer and spring. Neritic, warm-water species. (YAMAzI, 1959, p. 129)

Tintinnopsis radix (IMHOF)

Very common, at sometimes in swarms, in the innermost part of the bay. Neritic, steno. thermal, warm-water form. (YAMAZI, 1959, p. 128, 129)

\section{Tintinnopsis tubulosa Levander}

Very rare, in winter and spring. Neritic, cold-water species.

\section{Family 3. Codonellopsidae}

\section{Codonellopsis morchella (CLEVE)}

Very rare, found occasionally throughout the year. Neritic, eurythermal from tropical to boreal. (YAMAZI, 1959, p. 176). In September (IKARI, MS.)

\section{Codonellopsis nipponica Hada}

Very rare, neritic, warm water form.

\section{Codonellopsis parva Koford et CAMPBell}

Rare, in summer, oceanic, warm-water species. (YAMAZI, 1959, p. 176, 202). In September (IKARI, MS.)

\section{Codonellopsis ostenfeldi (SCHMIDT)}

Very rare, neritic, warm-water species.

\section{Stenosemella nivalis (MEUNIER)}

Rare, all the year round, in inlet area. Neritic, eurythermal, from tropical to boreal. In September. (IKARI, MS.)

\section{Family 4. Coxliellidae}

Coxliella ampula (JöRGENSEN)

Very rare, in cold seasons, inside the inlet. Neritic, widespread species. In March. (IKarI, MS.)

\section{Coxliella longa (BRANDT)}

Oceanic, warm-water species. In September. (IKARI, MS.)

Helicostomella subulata (EHRENBERG)

Very rare, outside and inside the bay, in winter and spring. Widely distributed, cold-water species. In March. (IKARI, MS.)

\section{Helicostomella longa (BRANDT)}

Fairly common, in the innermost part, in spring and summer. Neritic, warm-water species. In September (IKARI, MS.)

\section{Family 5. Cyttarocylidae}

\section{Cyttarocylis acutiformis KofoID et CAMPBELL}

Very rare, outside, in summer. Oceanic, warm-water species. In November. (IKARI, MS.)

Cyttarocylis brandti KoFOID et CAMPBELL

Very rare, outside the bay, in summer. 


\section{Favella azorica (Cleve)}

Rare, occasionally found in the bay. Widespread, neritic. Tropical warm-water species.

Favella ehrenbergii CLAPARÉde et LACHMANN

Common in the inlet, summer and autumn. Neritic, warm-water species.

Favella taraikaensis HADA

Very common, in the inner part of the bay, late spring and summer. Widespread. Neritic, temperate species. (YAMAZI, 1959, p. 56, 103, 129)

Poroecus a piculatus (Cleve)

Very common, inside, in early summer. Neritic, warm-water species.

\section{Family 6. Ptychocylidae}

Epiplocylis calyx (BRANDT)

Very rare, in open sea water. Oceanic tropical species. In November. (IkARI, MS.)

Epiplocylis undella (OSTENFELD et SCHMIDT)

Very rare, inside and outside the inlet, especially, in summer. Oceanic, tropical warm. water species.

Epiplocylis undella constricta KOFOID et CAMPBELL

Very rare, in open sea water near the mouth. Oceanic, warm-water species. (YAMAZr, 1959, p. 202). In September (IKARI, MS.)

Epiplocyloides lata KofOID et CAMPBELL

Very rare, found in open water outside the bay, in summer. In November. (IKART, MS.) Oceanic, tropical warm-water species.

\section{Family 7. Petalotrichidae}

Metacylis corbula KOFOID et CAMPBELL

Very rare. In September (IKARI, MS.)

Metacylis mediterranea (MERESCHKOWSKY)

Very rare, found in open water, summer and autumn. Oceanic, tropical warm-water species.

Petalotricha ampulla (FOL)

Oceanic, tropical warm-water species. In October. (IKARI, MS.)

Family 8. Rhabdonellidae

Protorhabdonella simplex (Cleve)

Warm-water species.

Rhabdonella amor (Cleve)

Oceanic. In October. (IKARI, MS.)

Rhabdonella elegans JÖRGENSEN

Very rare, in the open sea water outside the inlet, in warm seasons. Oceanic, warmwater species. In October. (IKARI, MS.) 
Rhabdonella poculum (OSTENFELd et Schmidt)

Very rare. Oceanic, warm-water species.

Rhabdonellopsis apophysata (CLEVE)

Very rare, open sea water, in summer. Oceanic, warm-water species. In July. (IKARI, MS.)

\section{Family 9. Xystonellidae}

Xystonellopsis heros (CLEVE)

Very rare. Oceanic, warm-water species (YAmAzI, 1959, p. 176). In October. (IKARI, MS.)

Xystonella scandens (BRANDT)

Oceanic. In November. (IKARI, MS.)

Xystonella treforti (DADAY)

Oceanic, warm-water species.

Family 10. Undellidae

Undella (-Proplectella) claparédei (ENTZ.)

Very rare, tropical, warm-water species. In October. (IKARI, MS.)

Undella californiensis KofoId et CAMPBELL

Very rare, inside and outside the bay, in cold seasons. Stenothermal, north-temperate species.

\section{Family 11. Dictyocystidae}

Dictyocysta reticulata KOFOID et CAMPBELL

Very rare, outside the inlet, in summer. Oceanic, warm-water species,

\section{Family $12 . \quad$ Tintinnidae}

Amphorella quadrilineata (CLAP. et LAChMANN)

Rare, inside and outside, in winter and spring. Neritic, ubiquitous, eurythermal form, tropical to boreal.

Amphorellopsis acuta (ScHMIDT)

Very rare, occasionally found in summer. Oceanic, warm-water species.

Dadayiella bulbosa (BRANDT)

Very rare, found in summer. Oceanic, warm-water species.

Dadayiella ganimedes (ENTZ.)

Very rare, found in summer. Oceanic, warm-water species. In September. (IKARI, MS.)

Salpingella acuminata (Claparéde \& LaChMANN)

Rare, inside and outside, in spring and summer. Eurythermal, from tropical to boreal. In November. (IKARI, MS.) 
Steenstrupiella steenstrupi (ClAPARÉde \& LAChMANN)

Very rare, in summer. Oceanic, warm-water species. In November. (IkARI, MS.)

Tintinnus exiguus HADA

Rare, all the year round, but in early summer and spring. Stenothermal, north-temperate species.

\section{Tintinnus fraknoii DADAY}

Very rare, in summer. Tropical, warm-water species.

Tintinnus lusus-undae ENTz.

Common but not abundant, in all seasons, especially in summer. Neritic, warm-water species.

Tintinnus lusus-undae var. tenuis KOFOID \& CAMPBELL

Neritic, warm-water species.

\section{Tintinnus rectus WOLFES}

Very rare, inside and outside the bay, in cold seasons. Stenothermal, temperate species. (YAMAZI, 1959, p. 176). In February. (IKARI, MS.)

\section{Phylum COELENTERATA}

\section{Subphylum CNIDARIA}

\section{Class HYDROZOA}

Order HYDROMEDUSAE

Suborder ANTHOMEDUSAE

\section{Bougainvillia bitentaculata UCHIDA}

Found in early summer, rare, neritic.

Cladonema radiatum var. Mayeri Perkins

From early summer to late summer, neritic, common.

Cytaeis japonica UCHIDA

Common in early summer. (KomaI, 1931, p. 252)

\section{Dipurena ophigaster HAECKEL}

Summer, found almost everywhere, temperate specices, rare.

Euphysa bigelowi (MAAS)

Summer, found everywhere, warm-water species, rare.

Gotoea typica UCHIDA

In spring and early summer, rare.

\section{Halitiaria formosa FEwKES}

Rare, in late summer, in the bay.

\section{Hybocodon forbesii MAYER}

Rare, in late summer, in the bay.

Leuckartiaria octona (FLEMING)

HrRo (1939, p. 170)

Nemopsis dofleini MAAS

Common, in spring, in the outer and inner part of the inlet. 
Podocoryne simplex Kramp

In summer, common.

Proboscidactyla ornata BROWN

Rare, inside the bay.

Proboscidactyla ornata var. gemmifera MAAS

In summer, almost everywhere, rare. (YAMAZI, 1959, p. 131)

Proboscidactyla typica (UCHIDA) [= Misakia typica UCHIDA]

Rare, in early summer.

Rathkea octopunctata (SARS)

Rare, from winter to spring.

Sarsia nipponica UCHIDA

Rare, in late autumn, neritic. Warm-water species.

Spirocodon saltatrix (TILESIUS)

From winter to early summer, common inlet waters.

Stomotoca rugosa MAYER

Rare, in winter and early spring, neritic.

Tiaranna ikarii UCHIDA

Rare, in autumn.

Turritopsis nutricula MCCRADY

Rare, in summer, anywhere in the bay.

\section{Suborder LEPTOMEDUSAE}

\section{Aequorea coerulescens BRANDT}

In spring and early summer, common inside the bay.

Eucheilota paradoxica MAYER

In summer, rare, near the mouth.

Eutima japonica UCHIDA

In summer season, inner part of the bay.

Gastroblasta chenghanensis LING

Common, in spring and early summer. Neritic form. (KomaI et YAMAZI, 1944 ; Y AMAZI, 1959, p. 131)

Irenopsis hexanemalis GOETTE

Very common, in inner part of the bay, in warm seasons.

Obelia sp. 1

Very common in spring and early summer. Neritic form (YamazI, 1959, p. 30, 131)

Obelia sp. 2

\section{Order TRACHYLINA}

Suborder TRACHOMEDUSAE

\section{Aegina rosea Eschscholtz}

In winter and early spring. Common, almost anywhere in the inlet. 
Aglaura hemistoma Péron et Lesueur

From spring to summer, warm-water form. (YAMAZI, 1959, p. 30)

Geryonia proboscidalis FORSKÅL

In winter season, rarely found in the bay.

Liriope tetraphylla Chamisso et EysenhaRdT

Common, in autumn and winter. At times in swarms. (YAMAZI, 1959, p. 130)

Rhopalonema velatum GEgENBAUR

In common in the inlet waters.

Solmaris corona HAECKEL

Common in winter and spring, almost anywhere. (YAMAZI, 1959, p. 131)

Solmundella bitentaculata QuOY et GAIMARD

Common in spring and summer season. Oceanic, warm-water form. (YAMAZI, 1959, p. 130)

\section{Suborder LIMNOMEDUSAE}

\section{Gonionemus depressus Goto}

Very rare, in early summer, lodged on Zostera.

Olindias formosus (GoTO)

Common, in early summer, inside and outside the bay. (YamazI, 1959, p. 131)

Scolionema gemmifera KISHINOUYE

In spring and early summer, off Ezura. Very common. Lodged on Zostera.

\section{Order SIPHONOPHORA}

\section{Suborder CALYCOPHORAE}

\section{Abylopsis tetragona (Отто)}

Very common in our waters, in winter and spring.

Diphyes bojani (EschscholTz)

Common in the outer part of the inlet, in spring and early summer. (YAMAZI, 1959, p. 177)

\section{Diphyes chamissonis HUXLEY}

Rare, in the bay, in spring and early summer. Warm-water form.

Diphyes contorta LENS et VAN RIEMSDIJK

Rare, in open sea water near the mouth, in spring season. (YAMAZI, 1959, p. 178)

Diphyes dispar Chamisso et EysenhardT

Rare, in the bay, in spring and early summer. Warm-water form. (YAMAzr, 1959, p. 54, 178)

\section{Hippodius ungulatus HAECKEL}

Rare in our waters, in spring.

\section{Muggiaea atlantica CunNingham}

Very common, in almost all seasons, especially in winter. Eurythermal species. (YAMAZI, 1959, p. 178) 


\section{Muggiaea spiralis (BIGELOW)}

Common, in winter and spring seasons, in open sea water. (YAMAZI, 1959, p. 177)

Praya cymbiformis Delle Chiaje

Rare, in the open-sea water near the mouth, in spring and early summer. Oceanic, warmwater form.

\section{Suborder PHYSOPHORAE}

Agalma elegans. (SARS)

Rare, found in spring and early summer. Warm-water form.

Nanomia bijuga (Delle ChIAJE) [= Cupulita picta ChUN $_{\text {? }}$

Rare in the bay, occasionally found in spring season. Oceanic, warm-water form.

\section{Physophora hydrostatica FORSKÅL}

Rare in the bay, in spring. Warm-water form.

\section{Suborder CYSTONECTAE}

Physalia physalis utriculus La Martiniere

Occasionally common, especially in summer, drifted ashore. (YAMAZI, 1959, color pl. 1.)

Rhizophysa eysenhardtii GEGENBAUR

Rare, in spring season.

Rhizophysa filiformis (FORSKÅL)

Rare near shore, in open water near the mouth, in spring.

Suborder DISCONECTAE

Porpita porpita (Linné) ( $=$ P. umbella O. F. Müller)

Very common in late spring and early summer. Sometimes in swarms, drifted ashore. (YamAZI, 1959, p. 30)

Velella velella (LINNÉ) $[=V$. lata Chamisso et EysenhardT $]$

At times very common, drifted ashore, in late spring and summer.

\section{Class SCYPHOMEDUSAE (SCYPHOZOA)}

\section{Order CUBOMEDUSAE}

\section{Charybdea rastoni HAECKEL}

Common in summer and autumn.

Tamoya bursalis HAEckel $[=T$. alata RAynaud; $T$. virlenta Kishinouye $]$

Rather rare, sometimes in swarms, in late summer and autumn. Known as a stinging medusa. (UCHDDA, 1926) 


\section{Order CORONATAE}

\section{Nausithoë punctata KÖLLIKER}

Common in winter and spring. Scyphopolype named "Stephanoscyphus racemosus Komai" are common on submerged rocks along an islet Tôsima in front of the Laboratory. (UCHIDA, 1926; KomaI, 1935)

\section{Order SEMAEOSTOMAE}

\section{Aurellia aurita (LINNE) LAMARCK}

Most abundant in the inner part of the bay, in spring and summer. Ephyrae appear in aquarium. (UCHIDA, 1926; OKADA, 1949, p. 355 ; YAMAZI, 1959, p. 60)

\section{Cyanea nozakii KISHINOUYE}

Rare in the bay, in winter.

Dactylometra pacifica GOETTE [ $=D$. ferruginaster; D. longicirra]

Very common in the bay, in spring and early summer. (UCHIDA, 1926)

Pelagia panopyra PÉron et LESUeur

Fairly common near the mouth of the bay, in spring and early summer. Warm current form. (UCHIDA, 1926)

\section{Sanderia malayensis GOETTE}

Common in summer. Warm-water form. (UcHIDA, 1926)

\section{Order RHIZOSTOMAE}

\section{Cephea cephea (ForSKÅL)}

Very rare, in open sea water near the mouth of the bay, in autumn. Warm-water form.

\section{Mastigias papua L. Agassiz}

Very common, in the inner part of the bay, in autumn. Inlet warm-water form. (YAMAZI, 1959, color pl. 1.)

\section{Netrostoma setouchiana KISHINOUYE}

Rare in the bay, occasionally in autumn, in coastal waters. (UCHIDA, 1926)

\section{Class ANTHOZOA}

Order ZOANTHARIA

Suborder ACTINIARIA

\section{Boceroides memurrichi (KWIETNIEWSKI)}

Common, near the shore found throughout the year.

\section{Subphylum CTENOPHORA \\ Order CYDIPPIDEA}

Euchlora rubra (Kölliker)

Very rare. (KomaI et TokiokA, 1942)

$$
-139-
$$




\section{Hormiphora palmata $\mathrm{CHUN}_{\mathrm{N}}$}

Rare, in the outer part of the bay, in spring and early summer.

Pleurobrachia pileus VANHÖFfEN

Very rare, in spring, in the mouth. (YAMAZI, 1959, p. 60, 123)

\section{Order LOBATEA}

\section{Bolinopsis mikado (MOSER)}

Common in the coastal waters, in spring season, sometimes very abundant.

\section{Eurhamphaea vexilligera GEGENBAUR}

Very rare. (Komal et TokJokA, 1942)

Kiyohimea aurita Komal et ToKioka

Very rare, found only in winter. (KomaI et TokiokA, 1940)

\section{Leucothea japonica KOMAI}

Abundant in the bay, in winter and spring.

Ocyropsis fusca (RANG)

Rare, sometimes in swarms, in spring season.

\section{Order CESTIDEA}

\section{Cestum amphitrites Mertens}

Very rare in the bay, in spring season.

\section{Order BEROIDEA}

\section{Beroë cucumis FABRICIUS}

Very common, inside the bay, occasionally very abundant, in spring and early summer.

\section{Phylum ASCELMINTHES \\ Class ROTIFERA}

\section{Encentrum sp.}

Common but never abundant, in the inner part of the bay, early summer. Neritic and littoral form. (YAmAzr, 1959, p. 103)

\section{Synchaeta sp.}

Rarely found, inside the bay, chiefly in spring and summer. Neritic and littoral species.

\section{Phylum ANNELIDA}

\section{Class CHAETOPODA}

\section{Alciopa cantrainii Delle Chiaje}

Very rare, in summer, near the mouth of the bay. 


\section{Autolitus sp.}

Very rare, in summer, near the mouth of the bay.

\section{Rhynchonerella fulgens GREEFF}

Very rare, in summer.

Sagitella kowalewskii N. WAGNER

Very rare, in summer. Warm-water form.

\section{Tomopteris elegans CHUN}

Very rare, found occasionally in summer, in open sea water outside the bay. Oceanic, warm-water form. (YAMAZI, 1959, p. 110, 120)

\section{Tomopteris pacifica IZUKA}

Very rare, oceanic, warm-water form.

Tomopteris septentrionalis De Quatrefages

Very rare, oceanic, warm-water form.

\section{Tomopteris sp.}

Rare, found in warm seasons. Oceanic, warm-water form.

\section{Typhloscolex Mülleri Busch}

Very rare, found in warm season, near the mouth of the bay.

Typhloscolex sp. 1

Typhloscolex sp. 1

Vanadis grandis IzUKA

Pelagic polychaete sp. 1

Pelagic polychaete sp. 2

Pelagic polychaete sp. 3

Pelagic polychaete sp. 4

Pelagic polychaete sp. 5

Pelagic polychaete sp. 6

\section{Phylum CHAETOGNATHA}

\section{Eukrohnia hamata (MöвIUs)}

Very rare, in the outer part of the bay. Oceanic, warm-water form. (YAMAZI, 1959, p. 211)

\section{Krohnitta pacifica (AIDA)}

Very rare, in Feburary. (TokiokA, 1954)

\section{Pterosagitta draco (KROHN)}

Very rare, in the inlet, but sometimes common in early spring in front of the Laboratory. (YAMAZI, 1959, p. 190). Found in winter (TOKIOKA, 1954).

\section{Sagitta bedoti BÉRANECK}

Very common in the bay, especially the outer parts, in summer. Oceanic, tropical species. (YAMAZI, 1959, p. 190)

\section{Sagitta bipunctata QUOY et GAIMARD}

Oceanic, subtropical and temperate species. (Yamazi, 1959, p. 192) 


\section{Sagitta delicata TOKIOKA}

Very common, in the inner part of the bay, throughout the year, especially in summer. Neritic and littoral, south-temperate species. (YAMAZI, 1959, p. 58, 126)

Sagitta enflata GrassI

Very common, in the open sea water out of the bay, in almost all seasons. Oceanic, tropical species. (TokIOKA, 1954; YAMAZI, 1959, p. 57, 110, 191)

\section{Sagitta hexaptera KROHN}

Rare, outside the bay, in spring and summer. Oceanic, subtropical and temperate species.

\section{Sagitta lyra KroHN}

Common, in the bay, from late spring to autumn. Oceanic, warm-water form. (YAMAzI, 1959, p. 190). In early summer relatively common. (ТокјоKA, 1954)

\section{Sagitta minima GRASSI}

Very common, in warm seasons. Oceanic, south-temperate species. (YAMAZI, 1959, p. 192) Common in spring. (TOKIOKA, 1954)

\section{Sagitta neglecta AIDA}

Rare, occasionally abundant, in warm seasons. Oceanic, warm water-species. (YAMAzr, 1959, p. 193)

Sagitta regularis AIDA

Common in open sea water near the mouth, in spring and summer. Oceanic, warm-water species. (Y AMAzI, 1959, p. 193)

\section{Sagitta robusta DONCASTER}

Rare, near the mouth, in warm season, oceanic, tropical species. (Y AMAZI, 1959, p. 193)

Sagitta serratodentata atlantica f. pseudoserratodentata ToKIOKA

Rare, in the bay, in warm season. Oceanic, warm-water species. Very rare, in February. (ТоктокА, 1954)

\section{Sagitta serratodentata pacifica KROHN}

Very common, in the bay, in warm season, oceanic, warm-water form (YAMAZI, 1959, p. 191). Very abundant in early spring (ТокјоK., 1954).

Spadella cephaloptera (BuSCH)

Rare, in February (TokiokA, 1954).

\section{Phylum MOLLUSCA}

\section{Class GASTROPODA}

\section{Subclass PROSOBRANCHIA}

\section{Order PTENOGLOSSA}

\section{Ianthina janthina (LINNE)}

Commonly drifted ashore in summer and autumn. Oceanic, warm-water form. (YAMAzI, 1959, p. 55)

Ianthina prolongata BLAINVILLE $[=I$. globosa SwAINSON

Commonly drifted ashore, in summer. (YAmAZI, 1959, p. 55) 


\section{Ianthina umbilicata D'ORBIGNY}

Very commonly drifted ashore in summer and autumn. Oceanic, warm-water form. (YamAzI, 1959, p. 50)

\section{Peraclis reticulata (D'OrBIGNY)} p. 50)

Very rarely drifted ashore, in warm season. Oceanic, warm-water form. (YAMAzI, 1959,

\section{Recluzia montrouzieri BRAZIER}

Rarely drifted ashore, in warm season. Oceanic, warm-water form. (TokIokA, 1953, p. 57)

\section{Section Heteropoda}

\section{Atlanta gaudichaudi SOULEyeT}

Rare, often in tow-netting. Oceanic, warm-water form.

Atlanta inclinata SOULEYET

Very rare, often in tow-netting. Oceanic, warm water-form.

Atlanta lesueuri Souleyet $[=A$. oligogyra Tesch]

Very rare, found in warm season. Oceanic, warm-water form.

Atlanta pacifica ToKIoKA

Very rare, found occasionally in tow-netting. Oceanic, warm-water form.

Atlanta peroni Lesueur

Rarely found in the inlet. Oceanic, warm water form.

Carinaria cristata (LINNE)

Rare, found in tow-netting, in warm season, very rarely drifted ashore.

Firoloida desmaresti Lesueur $[=F$. kowalewskyi VAyssière $]$

Very rarely drifted ashore in front of the Laboratory. (YAMAZI, 1959, p. 184)

Oxygyrus keraudreni (LESUEUR)

Very rarely drifted ashore.

Pterotrachea coronata FORSKÅL $[=P$. challengeri TESCH $]$

Very rarely drifted ashore. Oceanic, warm-water form. (YAMAzI, 1959, p. 58)

\section{Subclass OPISTHOBRANCHIA}

\section{Order NUDIBRANCHIA}

\section{Cephalopyge orientalis BABA}

One specimen was found by Mr. Y. MiYasita. (BABA, 1933)

\section{Order PTEROPODA}

Cavolina columnella columnella (RANG)

Very rare, drifted ashore. Oceanic, warm-water form.

Cavolina gibbosa gibbosa (RANG)

Very rare, drifted ashore. Oceanic, warm-water form. 


\section{Cavolina globulosa (RANG)}

Very rare. Oceanic, warm water form.

Cavolina inflexa labiata (D'ORBIGNY)

Rare, drifted ashore. Oceanic, warm-water form. (YamazI, 1959, p. 50)

Cavolina longirostris longirostris (LESUEUR)

Rare occasionally in swarms, in summer and autumn. Oceaic, warm-water form. (YAMAZI, 1959, p. 186)

\section{Cavolina quadridentata (LESUEUR)}

Rare, occasionally in swarms but not abundant, in summer. Oceanic warm-water form. (YAMAZI, 1959, p. 186)

\section{Cavolina tridentata (FORSKÅL)}

Very rare, occasionally in swarms. Oceanic, warm water form. (YAMAzI, 1959, p. 185)

Cavolina uncinata (RANG)

Rare, in open sea water near the mouth of the bay. Oceanic, warm-water form. (YAMAZI, 1959, p. 186)

\section{Clio pyramidata lanceolata TESCH}

Occasionally found in swarms, but not abundant, in late spring and summer. Oceanic, warm-water form. (YAMAZI, 1959, p. 51)

\section{Creseis acicula acicula RANG}

Common in our region, occasionally very abundant in summer. Oceanic, warm-water form. (YAMAZI, 1959, p. 122, 189)

\section{Creseis acicula clava RANG}

Common, oceanic, warm-water form.

Creseis virgula conica (ESCHSCHOLTZ)

Rare, in summer. Oceanic, warm-water form. (YamAZI, 1959, p. 51, 189)

\section{Creseis virgula virgula RANG}

Occasionally common, in late spring to summer. (YamAzI, 1959, p. 51, 189) Oceanic, warm-water form.

\section{Desmopterus papilio CHUN}

Rare, in open water near the mouth, in almost all seasons, especially in summer. Oceanic, warm-water species.

\section{Diacria quadridentata (LESUEUR)}

Very rare. Oceanic, warm-water form. Young form is Cleodora pigmaeus BoAs.

\section{Diacria trispinosa (LESUEUR)}

Very rare, found occasionally in open sea water near the mouth of the bay. Oceanic, warm-water form. Young form is Cleodora compressa Souleyet. (Yamazi, 1959, p. 185)

\section{Hyalaea complanata Gegenbaur}

Young form of Cav. tridentata tridentata ForSKÅL.

\section{Hyalaea depressa TESCH}

Young form of Cav. inflexa labiata (D'ORBIGNY). Rare, in open sea water near the mouth of the bay. (YAMAZI, 1959, p. 187)

Hyalaea laevigata D'ORBIGNY

Larval form of Cav. longirostris longirostris (LESSON). (YAMAZI, 1959, p. 187)

Hyalaea rotundata BOAS

Larval form of Cav. globulosa (RANG). 


\section{Hyalocylix striata (RANG)}

Very rare, occasionally drifted ashore in front of the Laboratory. (YAmAzI, 1959, p. 188)

Limacina trochiformis (D'ORBIGNY)

Very rare, in warm season.

\section{Styliola subula Quoy et GAIMARD}

Rare, found occasionally in open sea waters near the mouth of the bay. Oceanic, warmwater form. (YAMAZI, 1959, p. 188)

\section{Phylum ARTHROPODA Class CRUSTACEA \\ Subclass BRANCHIOPODA \\ Order CLADOCERA}

\section{Evadne nordmanni LOVÉN}

Very common, almost anywhere from winter to early summer. Neritic species. Widely distributed form.

\section{Evadne tergestina Claus}

Very common almost anywhere, especially in the inner part of the bay. Neritic and littoral form. (Yamazi, 1959, p. 65, 127)

\section{Penilia schmackeri RICHARD}

Very common, almost anywhere, in winter and early summer. Neritic and littoral, warmwater form. (YAMAZI, 1959, p. 65, 127)

\section{Podon leuckarti G. O. SARS}

Rare, almost anywhere, in early summer. Neritic and littoral form. (YAMAZI, 1959, p. 127)

Podon polyhemoides (LEUCKART)

Common, almost anywhere in the bay, in early summer. Neritic and littoral form. (YAMAZI, 1959, p. 65)

\section{Subclass OSTRACODA}

\section{Family 1. Halocypridae}

\section{Conchoecia hamata VÉVRA}

Found in open sea water near the mouth of the bay. Oceanic form. (YAMAZI, 1959, p. 182)

Conchoecia sp. 1

Conchoecia sp. 2

Conchoecia sp. 3

Conchoecia sp. 4

Conchoecia sp. 5

Conchoecia sp. 6

Conchoecia sp. 7 
Conchoecia sp. 8

Conchoecia sp. 9

Conchoecia sp. 10

Euconchoecia sp.

Rare, in open sea water near the mouth of the bay. Oceanic form. (YAMAZI, 1959, p. 182)

\section{Family 2. Cypridinidae}

Cylindroleberis oblonga (GRUBE)

Rare, near the coast. Tichopelagic form.

Cylindroleberis ovalis KaJIYAMA

Rare, near the coast. Tichopelagic form.

Cylindroleberis sp.

Rare, around the coast. Tichopelagic form.

Cypridina hilgendorfi G. W. MüLLER

Rare, all round the coast. Tichopelagic form.

Cypridina noctiluca KaJIYAMA

Very common, all round the coast. Tichopelagic form. (YAMAZI, 1959, p. 118, 143)

Cypridina pellucida Kajiyama

Very rare, all round the coast. Tichopelagic form.

Cypridina sp. 1

Tichopelagic form. All the year round, near the coast.

Cypridina sp. 2

Tichopelagic form. All the year round, near the coast.

Philomedes ijimai KajIyama

Tichopelagic form, coming up to the surface at night. (YAmAzI, 1959, p. 143)

\section{Subclass COPEPODA}

Order EUCOPEPODA

Suborder CALANOIDA (GYMNOPLEA)

Family 1. Calanidae

Calanus finmarchieus (Gunnerus) $[=$ C. helgolandicus (Claus)]

Common, throughout the year, especially in early summer and autumn, outside the inlet. Widespread species. (YamAzI, 1959, p. 68, 107, 111, 115)

Calanus minor (Claus)

Rare, in open sea water near the mouth of the bay, in summer and autumn. Warm-water species.

\section{Calanus tenuicornis (DANA)}

Rare, in open sea water near the mouth of the bay, in summer. Oceanic, subtropical and south-temperate form. 


\section{Canthocalanus pauper (GIESBRECHT)}

Common near the mouth, in all seasons, especially in warm season. Oceanic, tropical and subtropical species.

\section{Neocalanus gracilis (DANA)}

Very rare, in open sea water near the mouth of the bay, in summer and autumn. Oceanic, warm-water species.

\section{Neocalanus robustior (GIESBRECHT)}

Rather rare, in open sea water near the mouth of the bay, in summer. Warm-water species.

\section{Undinula darwini (LuBBock)}

Rare, near the mouth of the bay, more or less common in warm season. Oceanic, tropical species.

\section{Undinula vulgaris (DANA)}

Rare, in open sea water near the mouth of the bay, in warm season. Tropical, warm-water form.

\section{Family 2. Eucalanidae}

\section{Eucalanus attenuatus (DANA)}

Commonly throughout the year, especially in warm seasons. Oceanic, tropical and sub. tropical form. (YAMAZI, 1959, p. 107)

Eucalanus crassus Giesbrecht

Rare, at the mouth, in summer and autumn. Oceanic, warm-current form.

Eucalanus elongatus (DANA)

Very rare, at the mouth of the bay, in spring and early summer. Oceanic, north-tem. perate species.

\section{Eucalanus mucronatus GIESBRECHT}

Rare, near the mouth, in summer. Oceanic, warm-water species.

Eucalanus subcrassus GiesbrechT

Very rare, outside and inside the bay, in warm seasons. Oceanic, tropical species.

Eucalanus sp.

\section{Mecynocera clausi THOMPSON}

Not common in open sea water outside the bay, in warm seasons. (YAMAZI, 1959, p. 184)

Rhincalanus cornutus DANA

More or less common in open sea, especially in warm seasons. Oceanic, tropical and subtropical form.

Rhincalanus nasutus GiesBRECHT

Very rare, off Tanabe, in summer season. Oceanic, warm-water species.

\section{Family 3. Paracalanidae}

\section{Acrocalanus gibber GIESBRECHT}

Very rare outside the bay, in warm season. Oceanic, warm-water species.

Acrocalanus gracilis GIESBRECHT

More or less common, in open sea waters, in warm season. Oceanic, warm-water species. 


\section{Acrocalanus longicornis GIESBRecht}

Very rare, in open sea water, in summer and autumn. Oceanic, warm-water form.

Calocalanus pavo (DANA)

Rare, in open sea water, in summer season. Oceanic, tropical species. (Y.AmAzI, 1959, p. 107 , color pl. 2.)

\section{Calocalanus plumulosus (CLAUS)}

Very rare, in open sea water, in summer season. Oceanic, tropical species.

\section{Calocalanus styliremis GIESBRECHT}

Very rare, in open sea water, in summer and autumn. Oceanic, tropical species.

\section{Paracalanus aculeatus GIESBRECHT}

Fairly frequent in open sea water outside the bay, in warm season. Oceanic, tropical and subtropical form.

\section{Paracalanus parvus Giesbrecht}

Most abundant. The minor form inside the inlet, especially in warm season, while the major form outside the inlet, in warm season widely distributed, from oceanic and neritic to littoral, eurythermal species. (YAMAZI, 1959, p. 111, 125)

\section{Family 4. Pseudocalanidae}

\section{Clausocalanus arcuicornis (DANA)}

Very rare, in open sea water, in summer and autumn. Oceanic, warm-water species.

\section{Clausocalanus pergens FARRAN}

Very rare, in open sea water near the mouth, in summer. Oceanic warm-water species.

\section{Family 5. Aetideidae}

\section{Aetideus armatus (BofCK)}

Very rare, in open sea water, in warm season. Oceanic, tropical and subtropical species. Aetideus giesbrechti CLEVE

Very rare, in open sea water near the mouth, in summer. Oceanic, tropical and subtropical species.

\section{Euchirella amoena GIESBRECHT}

Very rare, in open water, in warm season. Oceanic, warm-water species.

\section{Euchirella rostrata GIESBRECHT}

Very rare, in open sea water near the mouth, in warm season. Oceanic, warm-water form. Euchirella sp.

\section{Family 6. Euchaetidae}

\section{Euchaeta flava GIESBRECHT}

Very rare, outside, in warm season. Temperate species. (YAmAzI, 1959, color pl. 2)

\section{Euchaeta marina PRESTENDREA}

Very common in all seasons, especially in warm season. (Y AMAZI, 1959, p. 108) 


\section{Euchaeta plana MORI}

Very rare, outside, in warm season. Oceanic, warm-water form.

Euchaeta wolfendeni A. SCOTT

Very rare, in warm season. Oceanic, tropical and subtropical species.

Euchaeta sp. 1

Euchaeta sp. 2

\section{Family 7. Phaennidae}

\section{Phaenna spinifera CLAUS}

Very rare, in open water, in summer. Oceanic, tropical and subtropical form.

\section{Family 8. Scolecithriciidae}

\section{Scolecithrix danae (LuBBOCK)}

Fairly common, near the mouth, in warm seasons.

\section{Family 9 . Centropagidae}

\section{Centropages abdominalis SATO}

Rare, inside the inlet, in winter and early spring. Neritic, north-temperate species.

\section{Centropages bradyi WHEELER}

Very rare, inside and outside the bay, in winter and early summer. North-temperate species.

\section{Centropages calaninus (DANA)}

Rare, outside the bay, in summer season. Oceanic, warm-water form.

Centropages elongatus GIESBRECHT

Very rare, outside, in warm season. Warm-water species.

\section{Centropages furcatus (DANA)}

Rare, Oceanic, frequently neritic, Widely distributed, warm-water form.

Centropages gracilis (DANA)

Rare, in open sea water, in warm season.

\section{Centropages orsinii GIESBRECHT}

Rare, inside and outside the bay, in summer. Warm-water species.

Centropages yamadai MORI [-C. tenuiremis THOMPSON \& SCOTT]

Rare, in the inlet, in autumn and spring. Temperate species.

Centropages sp. 1

Centropages sp. 2

\section{Family 10. Diaptomidae}

\section{Pseudodiaptomus marinus SATO}

Fairy common in the inlet, in winter and early summer, neritic. (YAMAZI, 1959, p. 111, 115) 


\section{Family 11. Temoridae}

\section{Temora discaudata Giesbrecht}

Fairly common inside and outside the bay, in warm water season. South-temperate and subtropical species.

Temora stylifera (DANA)

Very rare, outside the inlet, in summer and autumn. Oceanic, subtropical species.

Temora turbinata (DANA)

Very rare, in open sea waters, in summer and autumn. Oceanic, south-temperate species.

\section{Family 12. Metriidae}

\section{Pleuromamma abdominalis (LUBBock)}

Very rare, outside the inlet, in warm season. Oceanic, southern warm-water form. (YAMAZI, 1959, p. 121)

Pleuromamma gracilis (Claus)

Very rare, southern temperate species.

\section{Pleuromamma robusta GIESBRECHT}

Very rare, in open sea water, in warm season, Oceanic, southern warm-water form.

Pleuromamma xiphias Giesbrecht

Very, rare, southern warm-water form.

\section{Family 13. Lucicutiidae}

\section{Lucicutia flavicornis (Claus)}

Very rare. Oceanic, warm-water form.

Lucicutia ovalis WOLFENDEN

Very rare, in open sea water, in warm season. Oceanic, warm-water form.

Lucicutia sp.

\section{Family 14. Heterorhabdidae}

\section{Heterorhabdus papilliger (CLAUS)}

Very rare, in summer and autumn. Oceanic, warm-water form.

\section{Family 15. Augaptilidae}

Haloptilus acutifrons (Giesbrecht)

Very rare, oceanic warm-current species, in summer and autumn.

Haloptilus longicornis (Claus)

Very rare, in summer and autumn. Oceanic, warm-current species.

Haloptilus mucronatus (Claus)

Very rare, in summe. Oceanic, warm-current species. 


\section{Haloptilus oxycephalus (GIESBRECHT)}

Very rare, in summer and autumn. Oceanic, warm-current form.

\section{Family 16. Candaciidae}

Candacia aethiopia (DANA)

Very rare, in open water, in summer. Oceanic, warm-current form.

Candacia armata (BOECK)

Rare, in open sea water near the mouth, in summer and autumn. Warm-current form.

Candacia bispinosa (ClAUS)

Rare, in open sea water near the mouth, in summer. Oceanic, warm-water form.

Candacia bipinnata (GIESBRECHT)

Rare, outside and inside the bay, in spring and early summer. North-temperate species.

Candacia bradyi A. ScotT

Very rare, outside the bay, in summer. Oceanic, warm-water species.

Candacia catula (GIESBRECHT)

Very rare, at the mouth, in summer. Oceanic, tropical warm-current species.

Candacia curta (DANA)

Very rare, in open sea water near the mouth, in warm season. Oceanic, warm-water species.

Candacia longimana (Claus)

Very rare, at the mouth, in summer. Oceanic, warm-current species.

Candacia pachydactyla (DANA)

Very rare, in warm season, near the mouth. Oceanic, warm-water form.

Candacia pectinata BRADY

Very rare, near the mouth, in summer.

Candacia truncata (DANA)

Rare, at the mouth, in warm season. Warm-water form.

Candacia sp. 1

Candacia sp. 2

Family 17. Pontellidae

\section{Calanopia elliptica (DANA)}

Rare, near the mouth, in summer. Oceanic, warm-current species.

\section{Calanopia thompsoni ScOTT}

More or less common, widely distributed in inlet waters. Ubiquitous, warm-water form. (YAMAZI, 1959, p. 114)

\section{Labidocera acuta (DANA)}

Common, in open sea water, in summer and autumn. Oceanic, subtropical species.

Labidocera acutifrons (DANA)

Very rare, at the mouth, in summer and autumn. Oceanic, warm-current species. 


\section{Labidocera bipinnata TANAKA}

Rare, found almost everywhere in the bay, especially outside. Widely distributed, warmwater species. (YAMAZI, 1959, p. 114)

\section{Labidocera detruncata (DANA)}

Very rare, near the mouth, in summer, subtropical and south-temperate species.

Labidocera japonica MORI

More or less common, inside and outside the bay, in summer.

Labidocera kröyeri (BRADY)

Rare, outside and inside the bay, in warm season. Warm-water form.

\section{Labidocera pavo GIESBRECHT}

Common inside and outside the bay, in summer season, chiefly oceanic, but frequently neritic, and littoral.

Labidocera sp. 1

Labidocera sp. 2

Labidocera sp. 3

Labidocera sp. 4

Labidocera sp. 5

Labidocera sp. 6

Labidocera sp. 7

\section{Pontella chierchiae GIESBRECht}

Very rare, in open sea water near the mouth, in summer. Oceanic, warm-water species.

Pontella surrecta WILSON?

Very rare, near the mouth, in summer.

Pontella sp.

Pontellina plumata (DANA)

Rare, in summer and autum. Oceanic, warm-water form.

Pontellopsis armata GiesbeechT

Very rare, near the mouth, in summer. Oceanic, warm-water species.

Pontellopsis tenuicauda GIESBRECHT

Very rare, near the mouth, in summer. Warm-current species.

Pontellopsis yamadai MORI

Very rare, inside and outside the bay, in autumn and winter.

Pontellopsis sp. 1

Pontellopsis sp. 2

\section{Family 18. Acartiidae}

\section{Acartia clausi Giesbrecht}

Most abundant inside the inlet, from winter to early summer. Euryhaline, neritic, and littoral, temperate species. (YAmAzI, 1959, p. 71, 111, 124)

Acartia danae Giesbrecht

Temperate species, rare in the bay.

\section{Acartia erythraea GiesbrechT}

Very common inside the inlet, in warm season, in early summer and autumn. Neritic 
and littoral, warm-water species. (YAMAZI, 1959, p. 111, 124)

\section{Acartia hamata MORI}

Common inside the inlet, in summer and autumn. Neritic and littoral, warm-water form.

\section{Acartia negligens DANA}

Rare in the bay, in summer and autumn. Neritic warm-water species.

Acartia pacifica STEUER

Common in the inlet, in warm seasons.

Acartia spinicauda GIESBRECHT

Rare, in littoral area of the bay, in summer and autumn. Neritic and littoral, warm-water form.

\section{Family 19. Tortanidae}

\section{Tortanus forcipatus GIESBRECHT}

Common, in coastal and inlet waters, in warm seasons. Warm-water form. (YAMAzI, 1959 , p. 111, 115)

\section{Suborder CYCLOPOIDA (PODOPLEA)}

\section{Family 20. Oithonidae}

\section{Oithona decipiens FARRAN}

Rare, in open sea water outside the bay, in warm season. Oceanic, warm-water species.

\section{Oithona farax FARRAN}

Rare, oceanic, south-temperate, warm-water form.

\section{Oithona nana GIESBRECHT}

The most abundant copepod in the innermost part of the bay, in almost all seasons. Neritic or littoral, south-temperate, widespread form. (YAMAZI, 1959, p. 66, 124)

\section{Oithona plumifera BAIRD}

Common but not abundant in open sea water. Oceanic, south-temperate species. (YAMAzr, 1959, p. 184)

\section{Oithona rigida GIESBRECHT}

Sometimes abundant outer part of the bay in summer and autumn. Neritic warm-water form. (Y AmAzr, 1959, p. 124, color pl. 2)

\section{Oithona robusta GIESBRECHT}

Very rare found occasionally in summer and autumn. Oceanic, warm-water form.

\section{Oithona setigera DANA}

Rare, found in open sea water out of the bay. Oceanic, warm-water form.

\section{Oithona similis CLAUS}

Common in tow-netting in the outer part of the bay, in colder season. Neritic and oceanic, north-temperate but widely distributed form. (YAMAZI, 1959, p. 125)

\section{Family 21. Macrosetellidae}

\section{Macrosetella gracilis (DANA)}

Rare, in the open sea water outside the bay, in summer and autumn. Oceanic, tropical 
or subtropical species. (YAMAZI, 1959, p. 32,67)

\section{Miracia efferata DANA}

Only one species in the bay, in summer. Female in dark greenish blue.

\section{Family 22. Ectinosomidae}

\section{Microsetella norvegica (BOECK)}

Common, in winter and spring, outside the bay. Neritic, wide spread, occasionally oceanic, temperate species.

\section{Microsetella rosea (DANA)}

Fairly common, in warm season, outer part of the bay. Neritic, warm-water form. (YAMAZI, 1959, p. 125)

\section{Family 23. Tachdiidae}

\section{Euterpe acutifrons (DANA)}

Common, in the outer part of the bay, all the year round, neritic, sporadically oceanic, warm-water form.

\section{Family 24. Clytemnestridae}

\section{Clytemnestra rostrata (BRADY)}

Very rare, found occasionally in warm season, outside the bay. Oceanic, subtropical and south-temperate warm-water species.

\section{Clytemnestra scutellata DANA}

Very rare, oceanic subtropical warm-water species.

\section{Family 25. Oncaeidae}

\section{Lubbockia marukawai MORI}

Rare, in open sea water outside the bay, in summer. Warm-water form.

\section{Lubbockia squillimana CLAUS}

Rare, in open sea water outside the bay, in summer. Warm-water form.

\section{Oncaea media GIESBRECHT}

Abundant, sometimes in swarms, commonest in summer. Neritic and oceanic, subtropical and south-temperate, widespread form.

\section{Oncaea venusta PHILIPPI}

Most abundant in the outer part of the bay. Oceanic but frequently neritic, northtemperate species. (YAMAZI, 1959, color pl. 2)

Oncaea sp. 1

Oncaea sp. 2

\section{Family 26. Corycaeidae}

\section{Copilia mirabilis DANA}

Rare, in open sea not far from the Laboratory, chiefly in summer and autumn. Oceanic, 
tropical species. (YAMAZI, 1959, p. 57, 66, color pl. 2)

\section{Copilia quadrata DANA}

Very rare, outside, open sea water, in summer and autumn. Oceanic, tropical and subtropical form. (YAMAZI, 1959, p. 57)

Corycaeus affinis MURRICH (=Corycaeus japonicus MORI; Corycaeus anglicus)

Very common, inside and outside the inlet, in winter and spring season. Neritic, north temperate species.

Corycaeus asiaticus F. DAHL

Very rare, oceanic warm-water species.

Corycaeus catus F. DAHL

Rare, outside open water, in summer and autumn.

Corycaeus concinnus DANA

Very rare, outside, in summer. Oceanic, warm-water form.

Corycaeus crassiusculus DANA

Common, inside and outside the bay, in warm season. Oceanic form.

\section{Corycaeus flaccus GIESBRECHT}

More or less common, in summer and autumn. Oceanic, tropical species. (YAmAzI, 1959, color pl. 2)

\section{Corycaeus gibbulus Giesbrecht}

Rare, inside and outside the bay, in summer and autumn. Oceanic, warm-water form.

\section{Corycaeus lautus DANA}

Common, inside and outside the bay, in summer season. Oceanic, warm southern form.

\section{Corycaeus longistylis DANA}

Common, outside the bay, in summer. Oceanic, southern species.

\section{Corycaeus speciosus DANA}

Very rare, outside the inlet, in summer and autumn. Oceanic, tropical and subtropical species.

Corycaeus sp. 1

Corycaeus sp. 2

Corycaeus sp. 3

Corycaeus sp. 4

Corycaeus sp. 5

Corycaeus sp. 6

Pachysoma dentatum MORI

Very rare, open sea, in summer season. Oceanic, warm-water southern form.

Sapphirina angusta DANA

Very rare, in open sea water, in summer. Oceanic, warm-water species.

\section{Sapphirina gastrica GIESBRECHT}

Very rare, outside the inlet, in summer. Oceanic, warm-water species.

\section{Sapphirina gemma DANA}

Rare, in open sea water, in summer and autumn. Oceanic, warm-water species.

\section{Sapphirina intestinata GIESBRECHT} form.

Very rare, in open sea water, in summer. Oceanic, tropical and subtropical warm-current 


\section{Sapphirina nigromaculata CLAUS}

Very rare, in open sea water, in summer. Oceanic, warm-current form. (YAMAzI, 1959, p. 122)

Sapphirina opalina DANA

Rare, in open sea water, in summer and autumn. Oceanic, tropical and subtropical warmcurrent species. (YAMAZI, 195, color pl. 2)

Sapphirina stellata GIESBRECHT

More or less common, in open sea water, in summer. Oceanic, tropical and subtropical warm-current species. (Y AMAZI, 1959, p. 35, 122)

\section{Suborder MONSTRILLOIDA}

Family 27. Monstrillidae

\section{Haemocera morii ToKIOKA}

Very rare, in summer, in the bay. (TokIOKA, 1949)

Monstrilla sp. 1

Very rare, in the bay, in warm season. (YAMAzI, 1959, p. 114)

Monstrilla sp. 2

Monstrilla sp. 3

Monstrilla sp. 4

Monstrilla sp. 5

Monstrilla sp. 6

Suborder HARPACTICOIDA

Family 28. Harpacticidae

\section{Tigriopus japonicus MORI}

Very abundant in rock pools above high water mark, throughout the year, especially from spring to autumn. (YAMAZx, 1959, p. 104, 144)

Harpacticus sp. 1

Harpacticus sp. 2

Harpacticus sp. 3

Harpacticus sp. 4

Family 29. Idyidae

Idya sp. 1

Idya sp. 2

Idya sp. 3

Idya sp. 4

\section{Subclass MALACOSTRACA \\ Order LEPTOSTRACA}

\section{Nebalia bipes FABRICIUS}

Very rare. Tichopelagic, saprofagous form. 


\section{Order CUMACEA}

\section{Bodotria sp.}

Tichopelagic form, coming up to the surface at night. (Y AMAZI, 1959, p. 143)

Diastylis sp.

Tichopelagic form, coming up to the surface at night. (YAMAZI, 1959, p. 143)

Paradiastylis sp.

\section{Order MYSIDACEA}

\section{Proneomysis misakiensis II}

Common, all the year round, usually near the bottom in daytime and comes up to the surface at night.

\section{Siriella watasei NAKAZAWA}

Very common, in almost all seasons, widely distributed in the bay. Neritic, and littoral form, comes up to the surface at night. (YAMAZI, 1959, p. 116)

\section{Order AMPHIPODA \\ Suborder HYPERIIDEA \\ Family 1. Vibiliidae}

\section{Vibilia gibbosa Bovallius}

Very rare, found in open water near the mouth, in summer. Oceanic, warm-water form.

\section{Family 2. Paraphronimidae}

\section{Phronima colletti Bovallius}

Very rarely found in open water near the mouth, in summer. Oceanic, warm-water form. Phronima sedentaria (FORSKÅL)

Very rarely found in open water near the mouth, in summer. Oceanic, warm-water form. (YAMAZI, 1959, p. 109, 179)

\section{Phronimella elongata Claus}

Very rarely, found in open sea water near the mouth, in summer. Oceanic, warm-water form. (Yamazi, 1959, p. 179)

\section{Family 3. Hyperiidae}

\section{Hyperia galba (MONTAGU)}

Very rare, found chiefly in open sea water near the mouth, in summer.

\section{Hyperia latissima Bovallius}

Fairly common, almost all seasons, inside and outside the bay.

\section{Hyperia schizogeneios SteBbing}

Very rare, found in open sea water. 
Hyperia sp. 1

Hyperia sp. 2

Hy peria sp. 3

Hyperia sp. 4

Hyperia sp. 5

Hyperia sp. 6

Hyperia sp. 7

Hyperia sp. 8

Hyperia sp. 9

Hyperia sp. 10

Hyperioides longipes Chevreux

Very rare, in open sea water outside the bay, in summer and autumn. Oceanic, warmwater form.

Parascelus tyhoides Claus

Very rare, in open water outside the inlet, in summer. Oceanic, warm-water form.

Phronimopsis spinifera Claus

Very rare, in open sea water near the mouth, in summer. (YamazI, 1959, p, 180)

Themisto gracilipes Norman

Very rare, in open sea water outside the inlet, in summer. Oceanic, warm-current form.

\section{Family 4. Anchylomeridae (Phrosinidae)}

\section{Anchylomera Blossevillei MILnE EDWARDs} form.

Very rare, near the mouth of the bay, in summer and autumn. Oceanic, warm-water

\section{Euprimno macropus (CRERIN)}

Very rare, in open sea water near the mouth, in summer and autumn. Oceanic. Warm. water form.

\section{Phrosina semilunata Risso}

Rare, found occasionally met with near the mouth of the bay, in summer. Warmwater species. (YAMAZI, 1959, p. 109)

\section{Family 5. Platyscelidae}

\section{Platyscelus serratulus STEBBING}

Very rare, found occasionally near the mouth, in summer. Oceanic, warm-water species. Platyscelus sp.

Tetrathyrus forcipatus Claus

Very rare, found only near the mouth of the bay, in summer. Warm-water species.

\section{Family 6. Scelidae}

\section{Eupronoe minuta Claus}

Rare, found only near the mouth, in summer and autumn.

$$
-158-
$$




\section{Parascelus typhoides CLAUS}

Rare, found occasionally in summer, near the mouth. Warm-water species.

\section{Family 7. Lycaeidae}

Brachyscelus crusculus BATE

Very rare, outside and near the mouth of the bay, in warm season. Warm-water, oceanic species.

\section{Brachyscelus latipes StebBing}

Very rare, near the mouth of the bay, in summer. Warm-water species. (YAMAZI, 1959, p. 109)

\section{Family 8. Oxycephalidae}

\section{Glosocephalus sp. 1}

Very rare, near the mouth of the bay, in summer. (YAmAzI, 1959, p. 180)

Glosocephalus sp. 2

Very rare, near the mouth of the bay, in summer. (YAMAZI, 1959, p. 180)

Oxycephalus porcellus CLAUS

Very rare, found only near the mouth of the bay, in warm seasons. Oceanic, warmwater form. (YAmAzI, 1959, p. 180)

Oxycephalus sp.

Rhabdosoma sp.

Very rare, near the mouth of the bay, in summer. (YAMAZI, 1959, p. 180)

\section{Order EUPHAUSIACEA}

Euphausia sp.

Oceanic, warm-water form.

\section{Order DECAPODA}

\section{Lucifer typus MILnE EDWARDS [ $=$ L. raynaudii BATE]}

Very common, inside and outside the bay, in summer and autumn. Widely distributed, warm-water species. (YAMAZI, 1959, p. 32, 118, 121)

\section{Phylum PROCHORDATA Class UROCHORDA (TUNICATA) Subclass APPENDICULARIA (COPELATA)}

Appendicularia sicula FOL

Rare in the bay, in warm seasons. Oceanic, warm-water form. 


\section{Fritillaria charybdae LOHMANN}

Very rare, in open sea water.

Fritillaria fraudax LoHMANN

Very rare, occasionally found in open sea water.

Fritillaria haplostoma FOL

Commonest in the bay, in summer and autumn, at times in swarms. Oceanic, warmwater form. (YAMAZI, 1959, p. 198)

\section{Fritillaria formica FOL}

Fairly common in the bay. Oceanic, south-temperate form.

Fritillaria megachile FOL

Very rare. Oceanic, warm-water form.

Fritillaria pellucida (Busch)

Commonest in the bay, in warm seasons. Oceanic, warm-water form.

Fritillaria tenella LOHMANN

Common, inside and outside the bay. Oceanic, warm-water form. (Yamazi, 1959, p. 198)

Fritillaria venusta LoHMANN

Very rare, in open sea water near the mouth of the bay. Oceanic, warm-water form. (YAMAZI, 1959, p. 198)

\section{Megacercus huxleyi (RITTER)}

Rare, found almost anywhere, especially outside the bay in early summer. Oceanic, warmwater form. (YAMAZI, 1959, p. 200)

\section{Oikopleura cophocerca GEGENBAUR}

Rare, in open sea water near the mouth of the bay. Oceanic, warm-water form. (YAMAzI, 1959, p. $47,105,200$ )

\section{Oikopleura dioica FOL}

Very common in the bay throughout the year, especially in warm seasons. Inlet water form. (YamAZx, 1959, p. 127)

\section{Oikopleura fusiformis FOL}

Common, in open sea water near the mouth of the bay, frequently inside, in late spring and summer. Oceanic, warm water form. (YamazI, 1959, p. 200)

\section{Oikopleura gracilis LOHMANN}

Rare, in open sea water near the mouth of the bay, from early summer to autumn. Oceanic form.

\section{Oikopleura intermedia LOHMANN [ $=$ O. macrostoma AIDA]}

Very rare, found occasionally in open sea water near the mouth of the bay. Oceanic, warm-water form.

\section{Oikopleura longicauda (VOGT)}

Commonest, especially in late spring and summer. Oceanic, warm-water form. (YAMAzI, 1959, p. 200)

\section{Oikopleura parva LOHMANN}

Rare, in open sea water near the mouth of the bay. Oceanic form.

\section{Oikopleura rufescens FOL}

Common, in open sea water near the mouth of the bay, in summer and autumn. Oceanic, warm-water form. (YAMAZI, 1959, p. 200)

$$
-160-
$$




\section{Stegosoma magnum (LANGERHANS)}

Common, in open sea water near the mouth of the bay. (Y AmAZI, 1959, p. 200)

\section{Subclass THALIACEA \\ Order DOLIOLIDA (CYCLOMYARIA)}

\section{Doliolum denticulatum QuOY et GAIMARD}

Moderately frequent in the bay, in summer and autumn. Abundant at times in swarms. Oceanic, warm-water form. (YAmAzI, 1959, p. 59, 101, 194) Found almost throughout the year. (ToKIOKA, 1937, p. 219)

Doliolum gegenbauri ULJANIN $[-D$. tritonis HERDMAN $]$

Rare, in open sea water near the month of the bay, in spring and summer, sometimes in swarms. Oceanic, warm-water form. (YAMAZI, 1959, p. 104, 194)

Doliolum nationalis BORGERT

Very common outside the bay, sometimes in swarms, in spring and summer. (YAMAzI, 1959, p. 194)

\section{Order SALPIDA (HEMIMYARIA)}

\section{Cyclosalpa affinis (Chamisso)}

Abundant at times in swarms in summer. Oceanic, warm-water species. Found in water (TOKIOKA, 1937, p. 221)

Cyclosalpa komaii Ihle et Ihle-Landenberg [-C. virgula Komai]

Very rare, in open sea water, in winter and spring. (KomAI, 1932, TokIokA, 1937, p. 221)

Cyclosalpa pinnata (ForSKåL)

Very rare, in warm seasons. Oceanic, warm-water form.

Cyclosalpa pinnata var. polae (SIGL.)

Rare, in spring and summer, in the outer part of the bay. Oceanic, warm-water form. (YAMAZI, 1959, p. 195) Found in autumn and winter. (TokrokA, 1937 p. 220)

Iasis zonaria (PALLAS)

Rare, occasionally found in the outer part of the bay. (YAMAZI, 1959, p. 195) In autumn and winter. (TokiokA. 1937, p. 224)

Ihlea asymmetrica (FOWLER)

Rare, in open sea water, in spring and early summer. Oceanic, warm-water form. (YAMAzI, 1959, p. 195) Found in spring. (ToKIOKA. 1937, p. 222)

Pegea confoederata (FORSKÅA)

Common but not abundant, in winter and early summer, very abundant in February. (YAMAZI, 1959, p. 104, 196)

\section{Ritteriella picteti (APSTEIN)}

Very rare, from early spring to summer, in open sea water near the mouth of the bay. Oceanic, warm-water form. Found in winter. (TokIorA, 1937, p. 222)

\section{Salpa cylindrica CuvIER}

Common, in open sea water, especially in early spring and summer. (YAMAzI, 1959, p. 59, 197) Found in spring. (TокјокA. 1937, p. 230) 


\section{Salpa fusiformis Cuvier}

Fairly common in open sea water outside the bay, in almost all seasons, especially in spring and early summer. Oceanic, warm-water form. Found in winter. (TOKIOKA, 1937 p. 223)

Thalia democratica (FoRSKÅL) var. echinata ToKIOKA

Rare. Oceanic, warm-water form. Found in winter. (TokIokA, 1937, p. 229)

Thalia democrarica (FORSKÂL) var. orientalis TOKIOKA

Very common in almost all seasons, especially in spring and early summer. Oceanic, warm-water form. (YAMAZI, 1959, p. 196) Found almost throughout the year. (ToKIOKA, 1937, p. 226-229)

\section{Thetys vagina (Tilesius)}

Rare in the outer part of the bay, in spring and early summer. Oceanic, warm-water form. (YAMAZI, 1959, p. 197) Found in winter and spring. (ToKIoKA, 1937, p. 226)

\section{Order PYROSOMATA}

\section{Pyrosoma atlanticum atlanticum PÉroN}

Rare, in open sea water outside the bay, in spring and summer, very rarely drifted ashore. Oceanic, warm-water form. (YAMAZl, 1959, p. 119)

\section{Pyrosoma sp.}

Very rare, drifted ashore in fornt of the Laboratory, in warm season. (YAMAZI, 1959, p. 195)

\section{REFERENCES}

BABA, K, 1933. A pelagic nudibranch Cephalopyge orientalis nov. sp. from Japan. Annot. Zool. Japon., XIV (1), pp. 157-160.

HARADA, E. 1957. Ecological observations on the Japanese spiny lobster, Panulirus japonicus (Von Siebold), in its larval and adult life. Publ. Seto Mar. Biol. Lab., IV (1), pp. 99-120.

HIRO, F. 1939. Notes on the animals on Macrocheira kaempferi de Haan. III. Hydroids. Annot. Zool. Japon., XVIII (1), pp. 167-176.

IKARI, J. 1926. On some Chaetoceros of Japan, 1. Bot. Mag., 39 (478), pp. 517-534.

1927. On Bacteriastrum of Japan. Ibid., 41 (486), pp. 421-432. (With Japanese rés.)

1928. On some Chaetoceros of Japan, II. Ibid., 42 (497), pp. 247-262.

(MS) Sketches of plankton (Unpublished.)

KomaI, T. 1931. On the hydroid stage of Cytaeis japonica Uchida. Annot. Zool. Japon., XIII (3), pp. 255-258.

1932. On some Salpas occurring in the vicinity of Seto, with remarks on the enantiomorphism found in some aggregated forms. Mem. Coll. Sci., Kyoto Imp. Univ., Ser. B, VIII (1), pp. $65-80$.

1935. On Stephanoscyphus and Nausithö̈. Ibid., Ser. B, X (5), pp. 289-340.

KomaI, T. \& ToKIoKA, T. 1940. Kiyohimea aurita n. gen., n. sp., type of a new family of a lobate Ctenophora. Annot. Zool. Japon., XIX (1), pp. 43-46.

151.

KOMAI, T. \& YAMAZI, I. 1944. The asexual reproduction of the Hydromedusae Gastroblasta chenghanensis. Ibid., XXII (3), pp. 105-108.

OkadA, Yô K. 1949. Life of Scyphomedusae. Coll. et Breed., XI (12), pp. 354-363. (In Japanese.) 
TokiokA, T. 1937. Notes on salpas and doliolums occurring on the Pacific coast of middle Japan. Annot. Zool. Japon., XVI (3), pp. 219-232. 1938. Order Thaliacea. Fauna Nipponica, XIV (2). (In Japanese.)

1940. Phylum Chaetognatha. Ibid,, V (2). (In Japanese.)

1949. Droplets from the Plankton net. IV. Haemocera morii n. sp., a curious copepod belonging to the family Monstrillidae. Publ. Seto Mar. Biol. Lab., I (2), pp. 71-73.

1954 a. General consideration of Japanese appendicularian fauna. Ibid., IV (2-3), pp. 251-262.

$1954 \mathrm{~b}$. Droplets from the plankton net. XIII. Emergence of a dense patch of chaetognaths near the Laboratory. Ibid., III (3), pp. 359-360. pp. $361-368$.

1954 c. Ditto XIV. Record of a Scyllarid Phyllosoma near Seto. Ibid., III (3),

UCHIDA, T. 1926. Scyphostomae preserved in the Seto Marine Biological Laboratory. Zool. Mag., 38 (457), pp. 383-384. (In Japanese.)

1927. Studies on Japanese Hydromedusae. I. Anthomedusae. Jour. Fac. Sci. Imp. Univ. Tokyo, Sect. IV, Zool., I (3), pp. 145-241.

1928. Studies on Japanese Hydromedusae. II. Trachomedusae and Narcomedusae. Jap. Jour. Zool., II (1), pp. 73-97.

1929. Studies on the Stauromedusae and Cubomedusae, with special reference to their metamorphosis. Ibid., II (2), pp. 103-193.

1936. Class Scyphozoa. Fauna Nipponica, III (2). (In Japanese.)

YAMAZI, I. 1955. Plankton investigation in inlet waters along the coast of Japan. XVIII. Seasonal succession of zooplankton in the inner area of Tanabe Bay from June to October, 1954. Publ. Seto Mar. Biol. Lab., IV (2-3), pp. 311-320.

1956. Plankton investigation in inlet waters along the coast of Japan. XIX. Regional characteristics and classification of inlet waters based on the plankton communities. Ibid., V (2), pp. 157-196.

- 1958. A study on the productivity of Tanabe Bay (Part I). IV. On some plankton indicating the water exchange. Records Oceanogr. Wks. in Japan, Spec. Number 2, pp. 25-35.

1959. The plankton of Japanese coastal waters. Hokuryukan, Tokyo. (In Japanese.)

(In press.) 